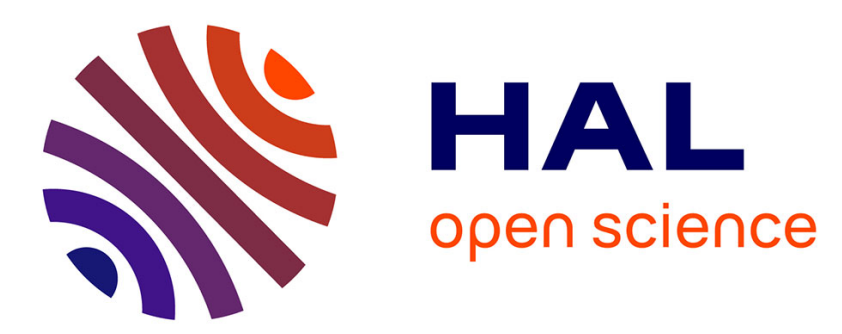

\title{
Metabolic signals in human puberty: Effects of over and undernutrion
}

\author{
G.Á. Martos-Moreno, J.A. Chowen, J. Argente
}

\section{To cite this version:}

G.Á. Martos-Moreno, J.A. Chowen, J. Argente. Metabolic signals in human puberty: Effects of over and undernutrion. Molecular and Cellular Endocrinology, 2010, 324 (1-2), pp.70. 10.1016/j.mce.2009.12.017 . hal-00602317

\section{HAL Id: hal-00602317 \\ https://hal.science/hal-00602317}

Submitted on 22 Jun 2011

HAL is a multi-disciplinary open access archive for the deposit and dissemination of scientific research documents, whether they are published or not. The documents may come from teaching and research institutions in France or abroad, or from public or private research centers.
L'archive ouverte pluridisciplinaire HAL, est destinée au dépôt et à la diffusion de documents scientifiques de niveau recherche, publiés ou non, émanant des établissements d'enseignement et de recherche français ou étrangers, des laboratoires publics ou privés. 


\section{Accepted Manuscript}

Title: Metabolic signals in human puberty: Effects of over and undernutrion

Authors: G.Á. Martos-Moreno, J.A. Chowen, J. Argente

PII: $\quad$ S0303-7207(09)00636-4

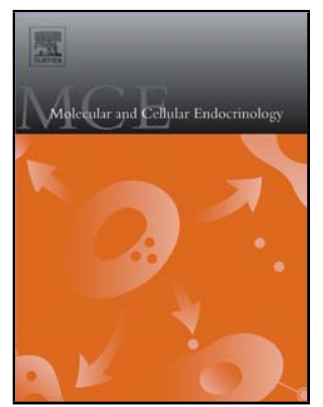

DOI: doi:10.1016/j.mce.2009.12.017

Reference: MCE 7398

To appear in: Molecular and Cellular Endocrinology

Received date:

$1-9-2009$

Revised date:

8-12-2009

Accepted date:

11-12-2009

Please cite this article as: Martos-Moreno, G.Á., Chowen, J.A., Argente, J., Metabolic signals in human puberty: Effects of over and undernutrion, Molecular and Cellular Endocrinology (2008), doi:10.1016/j.mce.2009.12.017

This is a PDF file of an unedited manuscript that has been accepted for publication. As a service to our customers we are providing this early version of the manuscript. The manuscript will undergo copyediting, typesetting, and review of the resulting proof before it is published in its final form. Please note that during the production process errors may be discovered which could affect the content, and all legal disclaimers that apply to the journal pertain. 


\section{Molecular and Cellular Endocrinology}

- Special Issue- NEUROENDOCRINOLOGY OF PUBERTY

Title: "Metabolic signals in human puberty: Effects of over and undernutrion".

Authors: $\quad$ Martos-Moreno GÁ, MD, PhD, Chowen JA, PhD, Argente J, M.D, PhD

Affiliation: Hospital Infantil Universitario Niño Jesús.

Department of Endocrinology.

Universidad Autónoma de Madrid. Departament of Pediatrics.

CIBER Fisiopatología Obesidad y Nutrición (CB 06/03). Instituto de Salud Carlos III.

E-28009, Madrid

Spain

Correspondence: Jesús Argente, MD, PhD

Professor \& Chairman

Department of Pediatrics \& Pediatric Endocrinology

Hospital Infantil Universitario Niño Jesús

Avda. Menéndez Pelayo, 65

E-28009, Madrid. Spain

e-mail: argentefen@terra.es

FAX: +34-915035939

Tel.: $\quad+34-915035915$ 


\section{Abstract: $\quad$ (250 words)}

Puberty in mammals is associated with important physical and psychological changes due to the increase in sex steroids and growth hormone $(\mathrm{GH})$. Indeed, an increase in growth velocity and the attainment of sexual maturity for future reproductive function are the hallmark changes during this stage of life. Both growth and reproduction consume high levels of energy, requiring suitable energy stores to face these physiological functions. During the last two decades our knowledge concerning how peptides produced in the digestive tract (in charge of energy intake) and in adipose tissue (in charge of energy storage) provide information regarding metabolic status to the central nervous system (CNS) has increased dramatically. Moreover, these peptides have been shown to play an important role in modulating the gonadotropic axis with their absence or an imbalance in their secretion being able to disturb pubertal onset or progression.

In this article we will review the current knowledge concerning the role played by leptin, the key adipokine in energy homeostasis, and ghrelin, the only orexigenic and growth-promoting peptide produced by the digestive tract, on sexual development. The normal evolutionary pattern of these peripherally produced metabolic signals throughout human puberty will be summarized. The effect of two opposite situations of chronic malnutrition, obesity and anorexia, on these signals and how they influence the course of puberty will also be discussed. Finally, we will briefly mention other peptides derived from the digestive tract (such as PYY) that may be involved in the regulatory link between energy homeostasis and sexual development.

Key words: Leptin, ghrelin, puberty, anorexia, obesity, growth 


\section{Outline}

1) Introduction

2) Metabolic signals from adipose tissue:

a) Leptin: the link between energy homeostasis and reproduction

b) Other adipokines

3) Metabolic signals from the digestive system:

a) Ghrelin: much more than a growth hormone secretagogue

b) Other signals derived from the digestive system
4) Final remarks
5) References
6) Figure legends 


\section{1) Introduction}

Puberty consists of the attainment of sexual maturation and fertility in a complex process that includes relevant somatic and behavioural changes. The hallmark of puberty is the reactivation of the hypothalamic pulsatile secretion of gonadotropin-releasing hormone $(\mathrm{GnRH})$, which activates the hypothalamicpituitary-gonadal (HPG) axis, and the production of sex steroids (Figure 1). This reactivation of $\mathrm{GnRH}$ production, which was previously present in the fetal and neonatal stages (Figure 2), takes place under the influence of several stimuli that are yet to be fully understood. Furthermore, there is a high variability between human individuals and different world populations in the timing of the onset and in the pace of progression of puberty, which is also not clearly understood (Figure 3).

Among the many factors influencing the neural networks controlling $\mathrm{GnRH}$ secretion, information about the status of metabolic fuel and energy stores is one of the cornerstones in the control of pubertal onset and progression. This concept, already postulated as early as the 1960s (Kennedy and Mitra, 1963), has later been supported by data arising from animal models and from epidemiological studies of the timing of puberty in humans in relationship to their nutritional status. These mechanisms of metabolic control are dynamic and result in the inhibition of the HPG axis in prolonged or intense situations of decreased energy availability, with the opposite occurring when energy becomes available. However, despite the experimental and epidemiological evidence suggesting common regulatory pathways of metabolism and reproduction, the precise neuroendocrine systems and peptides in charge of the coordinated control of reproduction and energy balance are still only partially known.

The long-standing hypothesis that energy homeostasis is controlled by a feedback system comprised of peptides from peripheral organs signalling to the central nervous system (CNS) has been confirmed by the accrual of an extensive body of knowledge during the last decades. The two main sources of these signals are the digestive tract, in charge of nutrient ingestion and absorption, and the adipose tissue, the major site of energy storage in the body (Meier and Gressner, 2004; Kershaw and Flier, 2004; Cummings and Overdui, 2007).

A major milestone in this field was the cloning, in 1994, of the adipocytederived hormone leptin (Zhang et al., 1994). The demonstration that its synthesis is directly related to the amount of body fat, thus energy stores, that it is involved in the control of energy homeostasis and that it modulates several neuroendocrine systems, including the HPG axis, turned leptin into the paradigm of a peptide involved in the integrated control of metabolism and sexual development. Subsequently, several additional peripherally produced peptides related to energy homeostasis control have also been shown to be involved in the modulation of the neural circuits controlling of pubertal development.

Much of our knowledge regarding the metabolic control of reproduction, especially at the cellular level, has been obtained from animal models. Although this information is of great importance for the advancement of our understanding, it should be kept in mind that the primate reproductive system has substantial differences from the most used experimental models, rodents. 
Thus, mechanisms proposed in rodent models may not be directly applicable to humans. Likewise, the reproductive axis is one of the clearest examples of sexual dimorphism. In addition to the most obvious sex differences, i.e., genitalia, gonads or cyclic changes in hormones, but there are also structural differences between the sexes at the level of the brain (Chen et al., 1990; Merchenthaler 1998). One clear example that highlights the differences between rodents and humans, as well as sex differences, is levels of circulating leptin. In post-pubertal humans females have significantly higher circulating leptin levels (Argente et al., 1997a; Martos-Moreno et al., 2006) and others (García-Mayor et al., 1997; Blum et al., 1997; Mantzoros et al., 1997; Ahmed et al., 1999; Falorni et al., 1999; Demerath et al., 1999), while in post-pubertal rats males have higher serum leptin levels (Landt et al., 1998). Hence, in this review, we have tried to specify from which sex the data were obtained and in which experimental model and the reader must keep these caveats in mind.

\section{2) Metabolic signals from adipose tissue}

\section{a) Leptin: linking energy homeostasis and reproduction}

a1. Leptin physiology

Leptin, the $16 \mathrm{kDa}$ product of the human LEP gene (7q31.3), which is homologous to the murine $o b$, is one of the most important adipokines in the control of energy homeostasis. It is mainly produced by subcutaneous differentiated adipocytes in direct relationship with their triglyceride content, although several other tissues can also produce this peptide (Meier and Gressner, 2004). Circulating leptin levels have been shown to be directly correlated with body fat content both in adults (Maffei et al., 1995) and in children and adolescents (Argente et al., 1997a) and peripheral leptin concentrations have been shown to decrease after food deprivation and to normalize after refeeding (Kolaczynski et al., 1996). Thus, leptin is considered to be an adiposity signal, as its levels are directly related to the amount of fat stored by the body (Woods and D'Alessio, 2008).

Leptin is secreted into the circulation in a pulsatile manner, with a significant diurnal variation that is present throughout pubertal development and in both males and females (Ankarberg-Lindgren et al., 2001; Yidiz et a., 2004). However, leptin's actions on target tissues is modulated by its binding to circulating truncated forms of its receptor (Smith et al., 2005).Leptin receptors belong to the class I cytokine receptor family and at least six different alternatively spliced isoforms (OB-Ra, Rb, Rc, Rd, Re and Rf) have been identified to date in mice and four (LEP-R5, R15, R67 y R274) in humans (Korner, et al. 2005). Rb/R274 is the longest isoform and the only one containing an intracellular signalling domain. The highest concentrations of this isoform are found in the hypothalamus and it is considered to be the mediator of leptin's central effects mainly through activation of the JAK (Janus kinase)/STAT (signalling transducer and activator of transcription) pathway. The shorter isoforms are thought to act as leptin transporters at different sites. Among these Re, which can also be produced by $\mathrm{Rb}$ ectodomain shedding, is the circulating form and acts as the major leptin binding protein in serum, modulating the amount of total and free leptin in the bloodstream (Kratzsch et al., 2002). Plasma leptin binding activity is modulated throughout development (Smith et al., 2005; Martos-Moreno, 2006); thus, the availability of this cytokine 
to perform its physiological functions is also modulated and should be taken into consideration.

Leptin crosses the blood-brain barrier (BBB) through a specific mechanism of transport, most likely mediated by leptin receptors (LRs), and reaches the cerebrospinal fluid (CSF) and the brain. At the level of the CNS leptin modulates several neuronal populations,, especially in the hypothalamus and brainstem, with LRs being abundantly expressed in the hypothalamic arcuate and paraventricular nuclei (Sone and Osamura, 2001). In energy homeostasis control, leptin mainly acts through the activation of neurons producing proopiomelanocortin (POMC) and cocaine amphetamine related transcript (CART) and inhibition of those producing neuropeptide $Y$ (NPY) and agouti protein related peptide (AgRP) in the hypothalamic arcuate nucleus (Ahima, 2005). Through its inhibitory action on NPY, leptin exerts many other central actions, affecting the adrenal, thyroid and somatotroph axes.

\section{a2. Leptin and pubertal development}

Regarding the role of leptin on the reproductive system, animal knockout models have shown that infertility is characteristic of leptin deficient mice $(o b / o b)$ and that this can be overcome by leptin treatment (Chehab et al., 1996). Similarly, humans that are leptin deficient due to homozygous gene mutations present with hypogonadotrophic hypogonadism, with long-term recombinant leptin treatment being able to achieve pulsatile nocturnal gonadotropin secretion in these patients (Farooqi et al., 1999). Additionally, humans with leptin receptor deficiency present different degrees of hypogonadotropic hypogonadism (Farooqui et al., 2007), which further stresses the importance of the leptin signalling pathway for the correct functioning of the gonadotropic axis.

Much debate has taken place as to whether leptin is a signal for the initiation of sexual maturation or if a critical leptin level is a condition for pubertal onset, acting as a permissive factor so that other critical processes of sexual maturation can occur. In this regard, the fact that the administration of small doses of leptin to mice in early puberty advanced sexual maturation, but that this effect could not be achieved in prepubertal animals supports the second option that leptin is a permissive signal for pubertal development (Gueorguiev et al., 2001). However, the observation of a nocturnal rhythm of leptin secretion and a nocturnal increase in leptin concentrations before puberty in rats does not allow us to completely rule out an eventual role of leptin in the timing of puberty onset (Nagatani et al., 2000).

We (Argente et al., 1997a; Martos-Moreno et al., 2006) and others (García-Mayor et al., 1997; Blum et al., 1997; Mantzoros et al., 1997; Ahmed et al., 1999; Falorni et al., 1999; Demerath et al., 1999) have studied the evolution of serum leptin levels throughout male and female physiological pubertal development. These studies have shown that serum leptin levels are low in prepubertal children of both sexes. In males leptin levels increase until Tanner stages II to III, varying between different studies, which precedes the testosterone increase (Mantzoros et al., 1997), and then decrease as puberty progresses. In contrast, serum leptin levels show a continuous and progressive increase in females throughout puberty. Thus, there is a sexual dimorphism in serum leptin levels and, although some authors suggest that it is already present in the prepubertal period, it is patent from mid-puberty onwards (Figure 
4A). Girls also show a higher pulse amplitude in the circadian rhythm of leptin secretion compared to boys (Sinha et al., 1996).

These data are consistent with the correlation found between serum leptin levels and body mass index (BMI) (Figure 4B), and even more so with body fat mass, in almost every study reported. This correlation between leptin levels and body fat mass is more pronounced in females (Ahmed et al., 1999) and supports the concept that the higher leptin levels found in girls is due to their higher level of fat content throughout development, as shown by densitometry (van der Sluys et al., 2002). Indeed, this difference in fat content is present from fetal life, but becomes more evident after puberty and in adulthood (Wells et al., 2007).

A decline in leptin binding activity has also been observed throughout puberty and this is due to a reduction in the serum levels of its soluble receptor (Quinton et al., 1999). Females have a much higher free leptin index than males at the beginning of the fertile period (Martos-Moreno et al., 2006), with the maximal sexual dimorphism occurring after the completion of puberty. In addition to the positive correlation observed between estradiol and leptin levels (Mantzoros et al., 1997), estradiol levels also correlate positively with the free leptin index (Martos-Moreno et al., 2006).

\section{a3. Leptin in models of malnutrition}

Two opposite models of malnutrition, one due to the lack and the other to the excess of energy availability, have also afforded valuable information about the importance of leptin in the activation and functioning of the gonadal axis. Hypothalamic amenorrhoea occurs as a result of intense physical exercise in up to $50 \%$ of female athletes as a consequence of impaired secretion of $\mathrm{GnRH}$, which leads to low gonadotropin and estrogen levels (Muñoz et al., 2002, 2004). This is coincident with reduced serum leptin levels and the absence of its normal diurnal pattern (Chan and Mantzoros, 2005). Similarly, studies in women (Chan and Mantzoros, 2005) and adolescents (Argente et al., 1997a) with anorexia nervosa have shown how this disease is associated with low leptin concentrations as a result of decreased fat mass and with a decrease in diurnal variations of leptin concentrations (Figure 5). In addition, in these patients circulating leptin is mainly bound to its receptor, resulting in a low free leptin index (Argente et al., 1997a) and thus limiting its bioavailability.

The degree of weight recovery after nutritional therapy in anorexic patients is correlated with the increase in their serum leptin levels (Argente et al., 1997a) (Figure 5). Furthermore, this rise in leptin correlates substantially with increasing gonadotropin levels, suggesting that the increase in circulating leptin associated to nutritional recovery could be involved in the activation of the HPG axis (Ballauff et al., 1999). Interestingly, not all anorexic patients recovering a normal body fat mass spontaneously attain menses resumption (García de Álvaro et al., 2007). Furthermore, circulating leptin levels can be similar in amenorrhoic and eumenorrhoic anorexic patients (Audí et al., 1998). It should be remembered that the etiology of anorexia nervosa is diverse and includes varying degrees of behavioral or psychiatric comorbidities (HerpertzDahlmann, 2009). Thus, it cannot be considered solely a model of malnutrition as these other factors may also influence the reproductive axis. However, the increase in free leptin index after nutritional therapy in anorexic patients has been associated with the resumption of menses (Misra et al., 2004), thus 
reinforcing the importance of the increase in leptin bioavailability on the HPG reactivation.

Interventional studies evaluating the effect of recombinant leptin in patients with hypothalamic amenorrhea have shown improved LH pulse frequency and increased serum LH levels, as well as an overall improvement in ovarian parameters (Welt et al., 2004). Likewise, exogenous leptin administration reversed anovulation induced by starvation in normal mice (Ahima et al., 1996). Based on these data several authors have suggested that the integrity of menstrual function depends critically upon a minimum level of free leptin, rather than upon a certain percentage of body fat, as postulated by Frisch in the 1970's (Frisch and Mc Arthur, 1974). Furthermore, it is suggested that leptin is a necessary signal for the reactivation of the HPG axis in this disease, but it is not sufficient by itself for the attainment of normal gonadal function, thus reinforcing the idea of leptin as a metabolic permissive factor, allowing gonadotropin secretion, but perhaps not triggering it directly.

Opposite to what is observed in anorexia, obesity in childhood can accelerate the onset of puberty. The advancement in the age at menarche in girls, coincident with the worldwide obesity epidemic, and much of the evidence available in the literature suggests that obesity may be causally related to earlier pubertal onset in girls. However, a recent study in Denmark demonstrates advancement of pubertal development in girls that is not associated with an increase in BMI (Aksglaede et al., 2009), while these same authors associated the advance in puberty in boys with an increase in BMI (Sorensen et al., 2009). Few studies have found a link between body fat and earlier puberty in boys, although it has been suggested that the lack of truly reliable markers of sexual development in boys (such as menarche in girls), and the lower correlation between $\mathrm{BMI}$ and fat mass due to muscle mass development in males could influence these findings (Kaplowitz, 2008).

In agreement with the previously stated positive correlation between serum leptin levels and BMI, obese children and adolescents have also been shown to have higher serum leptin levels than lean subjects (Argente et al., 1997a) (Figure 6), which decline significantly with weight loss (Argente et al., 1997a) (Figure 6). Setting aside the influence of obesity and hyperinsulinemia on adrenarche, the high leptin levels accompanying obesity seem to play a role in the eventual acceleration of pubertal maturation in obesity (Ahmed et al., 2009). Interestingly, long term effects of obesity and hyperleptinemia on gonadal function appear to be deleterious, as shown by the gonadal dysfunction observed in a high percentage of obese adults (Norman and Clark, 1999) and by the onset of hypothalamic hypogonadism in later life that occurs in transgenic mice that over express leptin (Yura et al., 2000).

\section{a4. Leptin's effects on the reproductive axis}

Leptin receptors have been identified in the gonadotrophs of the anterior pituitary (Jin et al., 1999), but evidence suggests that they are sparse (Magni et al., 1999) or even absent (Cunningham et al., 1999) in GnRH producing neurons of the hypothalamus. This indicates that, although direct stimulation of $\mathrm{GnRH}$ production by leptin could be possible, the involvement of intermediate circuits and signals in the stimulatory effect of leptin on the HPG axis must be prevalent. Indeed, leptin's effect on GnRH secretion may be mediated, at least in part, through kisspeptin producing neurons (Smith et al., 2006), as these 
neurons express leptin receptors and play a fundamental role in the modulation of $\mathrm{GnRH}$ secretion as discussed in detail in other chapters of this monograph. A dose dependent acceleration of $\mathrm{GnRH}$ secretion, but not of pulse amplitude, has been shown in neurons of the hypothalamic arcuate nucleus in response to leptin (Lebrethon et al., 2000 a). Furthermore, leptin and its receptor are expressed in the anterior pituitary (Jin et al., 1999) and leptin directly stimulates the release of LH and FSH via nitric oxide synthase activation (Yu et al., 1997).

An indirect mechanism for leptin's action on this axis has also been postulated. Leptin decreases the expression of NPY in the arcuate nucleus, and this in turn decreases the inhibitory action of NPY on pulsatile GnRH release (Plant et al., 2002). A similar mechanism, involving leptin stimulation of CART transcription and LHRH pulse shortening has also been reported (Lebrethon et al., 2000 b).

Leptin also has direct effects on the gonads. Indeed, in the testis, leptin is suggested to modulate proliferation, germ cell differentiation and steroidogenesis by both autocrine and paracrine mechanisms (Tena-Sempere et al., 1999; Tena-Sempere et al., 2001a; Fombonne et al., 2007; Herrid et al., 2008). In the adult rat testis, the leptin receptor is expressed in both Leydig and Sertoli cells (Tena-Sempere et al., 2001a), with the specific Ob-Rb isoform being expressed at higher levels during puberty compared to adulthood (TeneSempere et al., 2001b). The fact that leptin inhibits testosterone secretion at the level of the testis and there is a down-regulation of Ob-Rb in this organ after pubertal onset could be permissive to the increase in testosterone secretion.

The nutritional status during early development has also been shown to modulate the timing of pubertal onset and leptin may play a role in this process (Vickers et al., 2005; Gluckman and Hanson, 2006; Nunez-de la Mora et al., 2007). It is hypothesized that intrauterine signals affect later metabolic function in order to maintain reproductive fitness in the face of changing environments. Indeed, both over and undernutrition during early development have been linked to advancements in the age of pubertal onset and this is often associated with increased obesity and metabolic disturbances (Sloboda et al., 2009; Mericq 2006).

In summary, leptin is considered to be the main peripheral signal providing information about the body's energy stores to the hypothalamic circuits in charge of controlling energy homeostasis, thus communicating this information to the HPG axis by means of mechanisms that are far from being fully understood. Leptin appears to play a permissive role in the initiation of puberty and in the maintenance of the reproductive function. Nevertheless, to date there is insufficient evidence to consider leptin as the primary trigger for the onset of puberty.

\section{b) Other adipokines}

As previously stated, the different populations of cells in adipose tissue are the main source of several hormones (Kershaw and Flier 2004). In addition to leptin, much interest has been focused on two of these other adipokines in the past few years. These include adiponectin, almost exclusively produced by mature adipocytes, and resistin, mainly produced by the mononuclear cells in the stromal-vascular matrix of the adipose tissue (Korner et al., 2005). 
There is a clear sexual dimorphism in serum adiponectin levels starting at mid-puberty, with a significant decrease in males that is inversely correlated to androgen levels and positively correlated with the levels of sex hormone binding globulin (SHBG) (Bottner et al., 2004; Martos-Moreno et al., 2006). However, changes in serum resistin levels throughout puberty are quite different, with a peak at the completion of puberty found exclusively in females (Martos-Moreno et al., 2006). This peak correlates with the free leptin index and, thus, suggests a possible relationship between serum resistin and body fat content.

The effects of both of these adipokines are mainly linked to carbohydrate metabolism, but their link to energy homeostasis and HPG axis control has also been explored (Mitchell et al., 2005). In this regard, in vitro studies using rat hypothalamic neurons show that resistin, but not adiponectin, is able to modulate the production of several neurotransmitters involved in the central control of energy metabolism (Brunetti et al., 2004). Moreover, resistin has been shown to colocalize in neurons in charge of feeding behavior in the rodent hypothalamus (Wilkinson et al., 2005). Although these findings support a possible role for resistin in energy homeostasis control, experiments modifying resistin expression in adipose tissue or liver have reported no effects on sexual maturation or fertility (Pravenec et al., 2003; Banerjee et al., 2004; Rangwala et al., 2004).

The role of adiponectin in the control of energy homeostasis is uncertain, as unaltered feeding behavior has been shown in mice lacking (Maeda et al., 2002) or over-expressing adiponectin (Combs et al., 2004). However, this peptide has recently been shown to directly depolarize parvocellular neurons in the hypothalamic paraventricular nucleus, thus controlling neuroendocrine and autonomic functions (Hoyda et al., 2009). Regarding gonadal function, several studies in adiponectin ablated models failed to show any impairment of fertility (Kubota et al., 2002; Maeda et al., 2002; Ma et al., 2002). In contrast, female mice over-expressing adiponectin are infertile, although the precise etiology and extent of this infertility has not been elucidated (Combs et al., 2004). Consequently, an eventual role for adiponectin in linking energy homeostasis and control of the HPG axis cannot be excluded. Indeed, adiponectin has been shown to be produced by the gonads, with both the ovary and testis expressing adiponectin receptors (Chabrolle et al., 2007; Camino et al., 2008).

In rat ovary, adiponectin levels and the expression of its receptor AdipoR1 increase in response to hCG and pregnant mare serum gonadotrophin. Furthermore, adiponectin increases the production of both progesterone and estrogen in response to IGF-1 (Chabrolle et al., 2007). Circulating adiponectin levels have been associated with polycystic ovary syndrome in various studies, although this issue remains controversial (Yilmaz et al., 2009; Toulis et al., 2009; Senay et al., 2009)

Caminos and colleagues have demonstrated that adiponectin is also produced in the rat testis and detected primarily in the cytoplasm of the interstitial Leydig cells (Camino et al, 2008). Adiponectin is produced by the testis throughout development with the highest levels being found postpubertally. Although testicular expression of adiponectin was only slightly affected by gonadotropins, it was significantly increased by thyroxine and decreased by dexamethasone. In contrast to plasma levels, testicular 
adiponectin was not modulated by fasting. These authors also demonstrated that there are functional adipokine receptors in the testis and are also modulated during development and by gonadotropins. In addition, adiponectin was found to inhibit both basal and hCG-stimulated testosterone secretion.

Resistin is also expressed in the testis, with the maximum expression being found in the adult animal, being found in both the interstitial Leydig cells and Sertoli cells (Nogueiras et al., 2004). Testicular expression of this adipokine has been shown to be modulated by gonadotropins and fasting, with resistin stimulating testosterone secretion in a dose dependant manner (Nogueiras et al., 2004).

\section{3) Metabolic signals from the digestive system:}

The gastrointestinal (GI) tract and the pancreas are major sources of afferent signals involved in the central control of energy homeostasis, either through direct neural mechanisms or by the secretion of hormones to the bloodstream that can then cross the BBB (Banks, 2008). Most of these peptides are related to satiation, the feeling of fullness that leads to the termination of eating, and satiety, the prolongation of the interval between meals. The only known exception is ghrelin, which is known to be a powerful orexigenic signal (Woods and D'Alessio, 2008).

\section{a) Ghrelin: much more than a growth hormone secretagogue}

\section{a1. Ghrelin physiology}

Ghrelin is encoded by the GHRL gene (3p26-p25), which contains the sequence of a pre-pro-hormone named pre-pro-ghrelin. Its posttranslational modifications can also lead to the expression of obestatin, a peptide postulated to be the endogenous ligand of the $G$ protein coupled receptor 39 (GPR39), with its reported effects in hypothalamic POMC/CART and NPY/AgRP neurons being inverse to those exerted by ghrelin (Zhang et al., 2005). However, its ability to bind and activate GPR39 and its subsequent potential activities has been challenged (Chartrel et al., 2007).

Ghrelin is mainly produced by the oxyntic cells in the gastric mucosa, although it is also produced in the proximal intestine, pituitary, hypothalamus and other organs. It undergoes acylation at its serine amino acid at position 3 by a molecule of n-octanoyl acid (Kojima, et al., 1999). This acylation confers it the ability to cross the BBB and, more importantly, to bind the 1a (full length) subtype of the growth hormone secretagogue receptor (GHS-R) (Kojima et al., 1999, van der Lely et al., 2004, Fernández-Fernández et al., 2006), thus mediating most of the activities of ghrelin, although GHS-R1a independent actions have also been demonstrated (van der Lely et al., 2004).

Circulating ghrelin concentrations in normal lean subjects are pulsatile, with both diurnal and ultradian rhythms, with levels rising at night (Yidiz et al., 2004). Meal intake inhibits both ghrelin and des-acyl ghrelin, but long-term fasting appears to inhibit acylation but not total ghrelin secretion (Liu et al., 2008). Serum ghrelin levels are also influenced by growth and by pubertal 
development, with serum levels increasing during the first two years of extrauterine life, followed by a later decrease until the end of puberty (SorianoGuillén, et al., 2004b). A notable exception to both of these trends is displayed by patients affected with Prader-Willi syndrome, whose age-associated decrease in ghrelin levels is blunted. These patients show sustained hyperghrelinemia despite the existence of marked obesity (Haqq, et al., 2008). The sex difference in circulating ghrelin levels is controversial. A recent study reports that ghrelin levels are significantly higher in women than in men and demonstrates a correlation between testosterone levels and ghrelin in men and postmenopaousal women (Greenman et al., 2009).

There is a truncated isoform of the GHS-R (1b) that lacks two transmembrane domains and that is widely distributed throughout the body, although its precise role is not fully understood yet (van der Lely et al., 2004; Murphy, et al., 2006). In addition, the unacylated isoform of ghrelin is the most abundant form in plasma, and its specific receptor remains unknown. Despite that it was initially considered to be biologically inactive, it is now accepted that unacylated ghrelin has a wide range of actions that can overlap or antagonize those of the acylated isoform of the protein (Tena-Sempere, 2008).

\section{a2. Ghrelin and appetite control}

Ghrelin was first described as the endogenous ligand of the GHS-R, thus its function was initially linked to the stimulation of $\mathrm{GH}$ secretion (Kojima et al., 1999). As research on ghrelin's activities progressed, a wide range of both endocrine and non-endocrine functions were discovered for this peptide (van der Lely et al., 2004). Among these functions, its role in the regulation of energy homeostasis, this is, its ability to promote food intake and weight gain, has attracted the most attention (Kornonits et al., 2004, van der Lely et al., 2004). Ghrelin modulates energy homeostasis by stimulating the expression of the genes encoding NPY and AgRP in the arcuate nucleus of the hypothalamus and by binding to presynaptic terminals of arcuate NPY and POMC neurons, respectively stimulating and inhibiting their activity and peptide release (Lorenzi et al., 2009). This results in a net orexigenic effect, functionally opposite to that produced by leptin (Wynne, et al., 2005). In addition, i.c.v. but not peripheral administration of unacylated ghrelin has been shown to increase appetite through the GHS-R independent activation of hypothalamic orexin producing neurons (Toshinai, et al., 2006).

In agreement with its orexigenic role, serum ghrelin levels are influenced by both short and long term changes in energy homeostasis, with glucose, insulin and somatostatin levels being the major determinants. Circulating ghrelin increases in the fasting state, under the influence of sympathetic innervation, and decreases in the postprandial period, apparently regulated by non-vagal neurologic control influenced by the increase in insulin levels (Wynne, et al., 2005; Murphy, et al., 2006). Additionally, a long term decrease or increase in the body's energy stores (i.e., anorexia or obesity), leads to hyper- and hypoghrelinemia, respectively, with a negative correlation observed between BMI and ghrelin levels and a trend towards normalization of ghrelin levels after therapy (Soriano-Guillén et al., 2004a). Thus, ghrelin fulfils the criteria to be considered as a signal of starvation or energy insufficiency. 


\section{a3. Ghrelin's effects on pubertal onset}

Taken together, the previous stated observations in humans reinforce the role of ghrelin in reporting information regarding the fuel availability in the body to the CNS. These observations also suggest an inverse relationship between activation of the HPG axis and ghrelin levels and, thus, the possible involvement of ghrelin in the regulation of puberty and sexual function. These data could be summarized as: 1) the rise in ghrelin levels observed in the first two years of life is coincident with the decline in the GnRH activity observed at the beginning of extrauterine life; 2) the subsequent decrease in ghrelin levels associated with pubertal progression inversely mirrors the activation of the gonadal axis; 3 ) the inverse correlation between the body's energy stores and ghrelin levels, with the previously stated association between fuel availability and advanced (obesity) or impaired (anorexia) pubertal maturation; 4) patients affected with Prader Willi syndrome exhibit the coexistence of hyperghrelinemia and hypogonadotrophic hypogonadism, despite the existence of obesity.

We have previously stated how the onset of puberty is sensitive to the state of energy reserves, and how leptin could act as a permissive factor, informing as to whether these energy stores are sufficient to support pubertal development. The eventual influence of ghrelin, as a signal of energy insufficiency, on puberty onset and progression has been explored through the repeated administration of exogenous ghrelin to rats of both sexes at different stages of their pubertal development (Fernández-Fernández, et al., 2005a; Martini et al., 2006; Tena-Sempere 2008). The results of these studies show how, during the peripubertal period, repeated ghrelin administration results in lower LH and testosterone levels and the delayed onset of signs of pubertal maturation in male rats, whereas these markers were not influenced in prepubertal female rats (Fernández-Fernández, et al., 2005a). A deleterious effect of ghrelin on pubertal development has also been reported in pubertal female rats (Tena-Sempere 2008). Thus, a putative role of ghrelin, as a signal of energy insufficiency, in determining the onset and progression of puberty is suggested. Opposite to that stated for leptin, this effect would be predominant in the male sex rather than in the females, and its influence would depend on the pubertal stage.

\section{a4. Ghrelin's effects on the reproductive axis}

The effects of ghrelin on gonadotropin secretion have been studied in several mammalian species, with its central administration being shown to reduce LH pulse frequency in ovariectomized rats and monkeys and baseline LH levels in intact rats and sheep (Tena-Sempere 2008; Lorenzi T et al., 2009). Again, similar to the putative effect of ghrelin on puberty onset, this inhibitory effect of ghrelin on LH secretion appears to be more evident in male rats, either intact or gonadectomized and both in the prepubertal and in the adult stages, than in females. Its effects on FSH secretion are poorly characterized or only observed after the infusion of high doses of ghrelin (Tena-Sempere 2008). This predominant inhibitory effect of ghrelin on LH secretion seems to be exerted to a major extent through an inhibition of hypothalamic $\mathrm{GnRH}$ release, as shown by its effects on LH pulsatility and by studies employing hypothalamic explants (Fernández-Fernández et al., 2005b). Additionally, studies of the effects of ghrelin on pituitary explants show significant decreases in $\mathrm{GnRH}$-stimulated $\mathrm{LH}$ secretion, but also stimulatory responses after high doses, thus suggesting a 
possible direct effect of ghrelin on pituitary LH secretion (Fernández-Fernández et al., 2005b, Tena Sempere 2008). Ghrelin administration to healthy human subjects has also been shown to reduce baseline LH secretion, with reductions in both pulse amplitude and frequency, with no affect on FSH levels (Lanfranco et al., 2008).

Several mechanisms have been postulated to explain ghrelin's effects on LH secretion. These are: 1) A stimulatory effect of ghrelin on orexigenic neuropeptides such as NPY, AgRP and orexins, that play an inhibitory role in the central control of the HPG axis; 2) A possible interaction with the opioid system, as ghrelin has been shown to inhibit the stimulation of LH secretion by naloxone (Lanfranco et al., 2008); 3) The stimulation of corticotrophin-releasing hormone $(\mathrm{CRH})$ by ghrelin (Vulliémoz et al., 2008) and 4) The stimulation of prolactin secretion, as shown in adult humans (van der Lely et al., 2004).

Ghrelin influences the HPG axis by acting at different levels and it has been postulated that these actions can be driven both by the ghrelin released into the systemic circulation by the stomach and by the local production of this peptide in the CNS and gonads. However, a detailed description of the effects of ghrelin on gonadal function exceeds the aim of this article (for review see Lorenzi et al., 2009). However, to briefly mention the effect of ghrelin at different levels of the HPG axis, it is of note that the expression of ghrelin and of the GHS-R1a receptor has been documented in human testicle and ovary, as well as in several other species (Gaytan et al., 2005; Tena-Sempere 2008). In Leydig cells, ghrelin has been shown to inhibit stimulated testosterone production, to decrease the expression of several steroidogenic factors and to modulate proliferation and tubular function (Tena-Sempere et al., 2002; Barreiro et al., 2004). In an in vivo model of human granulosa-luteal cells, ghrelin has been shown to significantly inhibit estradiol and progesterone secretion in a dose dependent fashion (Vianni et al., 2008). The inhibitory effects on the sex steroid production by both the male and female gonads suggest an additional mechanism by which the normal functioning of the HPG axis can be inhibited during a hyperghrelinemic state, which is normally associated with a state of energy insufficiency.

The growth hormone secretagogue receptor (GHSR) (Howard et al 1996), an orphan 7-transmembrane G protein-coupled receptor (GPCR), was cloned as the target of a family of synthetic molecules named growth hormone (GH) secretagogues endowed with $\mathrm{GH}$ release properties (Smith et al 1997). This receptor is highly expressed in the brain and in the pituitary (Howard et al 1996). Recently, a natural mutation in the ghrelin receptor (GHRS-3q26.31-, Ala-204Glu) associated with a selective loss of constitutive activity without affecting ghrelin's affinity, potency or efficacy, that segregates in two families with short stature has been described (Pantel et al 2006). This first description of a functionally significant GHSR mutation, has resulted in the proposal that the selective lack of constitutive ghrelin receptor signaling could lead to a syndrome characterized not only by short stature, but also by obesity that apparently develops during puberty. Hence, these data raise the question of whether the increased body weight, present in several members of one of the families, reflects a direct effect of this GHRS mutation on energy homeostasis. Loss of function of the ghrelin or GHSR genes does not affect birth weight and early postnatal growth. However, ghrl(-/-) or ghsr(-/-) mice fed a high fat diet starting soon after weaning are resistant to diet-induced obesity, suggesting that ghrelin 
affects the maturation of the metabolic axes involved in energy balance. In addition, animal and human studies suggest that GHSR plays a physiological role in linear growth. In mice, absence of the GHSR gene is associated with lower insulin-like growth factor 1 concentrations and lower body mass in adult animals, independently of food intake (Chanoine et al 2009)

\section{b) Other signals from the digestive system}

As previously mentioned, most of the signals derived from the GI tract and involved in energy homeostasis, with the exception of ghrelin, are satiation or satiety signals. These include cholecystokinin (CCK), peptide YY (PYY), glicentin, glucagon-like peptide (GLP) 1 and 2, the bombesin family [bombesin, glucagon related peptide (GRP) and neuromedin B (NMB)], oxyntomodulin, enterostatin and apo A-IV. Moreover, the majority of these peptides (CCK, GLP1 and 2, PYY, GRP, NMB, oxyntomodulin and apo A-IV) are also synthesized in the brain (Woods, D'Alessio; 2008). Little is known about the eventual influence of these peptides on puberty onset and progression, although in recent years, some studies have postulated a role for PYY in the regulation of the HPG axis.

PYY belongs, in addition to NPY and the pancreatic polypeptide (PP), to the PP-fold peptide family. These peptides share the same G-protein coupled receptors (Y1, 2, 4, 5 and 6), as well as a common structure that is necessary for receptor binding (Gardiner, et al., 2008). PYY is secreted by the $L$ cells in the distal ileum and colon as $P Y_{1-36}$ and then is transformed into $P_{1} Y_{3-36}$ through the cleavage of its Tyr-Pro amino terminal residues by the enzyme dipeptyl peptidase IV (DPP-IV), located on the cell surface. Both PYY 1-36 and $\mathrm{PYY}_{3-36}$ can be found in peripheral blood, but the later is the most abundant. PYY secretion is stimulated by food intake, as well as by the presence of nutrients (mainly lipids) in the GI lumen, in proportion to caloric intake (Woods and D'Alessio, 2008). PYY locally decreases GI motility, can freely cross the BBB (Nonaka, et al., 2003) and has high affinity for the Y2 presynaptic receptor. It inhibits NPY release in the hypothalamic arcuate nucleus, thus decreasing appetite, as shown by the lack of this effect in the Y2 deficient mouse (Batterham and Bloom, 2003a). There is also evidence of the involvement of PYY in appetite control in humans, with obese subjects showing lower basal levels and a partially blunted postprandial PYY response compared to controls (le Roux, et al; 2006), although their sensitivity to exogenous PYY does not seem to be affected (Batterham, et al.; 2003b).

In a similar fashion to that previously stated for leptin and ghrelin, once it was accepted that PYY may contribute to energy homeostasis control through the hypothalamic circuits in charge of feeding stimuli (Coll et al.; 2004), several studies were conducted aiming to elucidate an eventual integrative role for this peptide between metabolic status and the gonadal axis. These studies, based upon the administration of PYY to animal models, have produced contrasting results regarding the effect of PYY on the gonadal axis, with the results depending on several factors including the sex, pubertal stage and nutritional status of the animal. For example, $\mathrm{PYY}_{3-36}$ enhances gonadotropin secretion from the pituitary of prepubertal rats, but also decreases $\mathrm{GnRH}$ secretion in vitro (Fernández-Fernández et al., 2005c). Furthermore, central administration of $\mathrm{PYY}_{3-36}$ in vivo shows opposite effects in prepubertal and adult male rats, 
inhibiting LH secretion in the former (Fernández-Fernández et al., 2005c) and enhancing it in the later (Pinilla et al., 2006). Thus, although the existence of a positive association between PYY levels, as a signal of energy availability, and the activity of HPG axis could be physiologically feasible, evidence of a precise integrating role between metabolic status and reproduction for PYY is lacking and its eventual mechanisms of action far from being understood.

Besides the GI tract itself, the pancreas is another major site of peptide secretion, including insulin, and the more recently characterized hormones pancreatic polypeptide (PP) and amylin, which are known to be involved in appetite control and energy homeostasis. Insulin is specifically produced by the $\beta$ cells in the pancreas and is in charge of maintaining blood glucose levels by stimulation of cellular glucose uptake. Conversely, insulin secretion is mainly regulated by glycemia, thus rising quickly after food intake. However, fasting serum insulin levels also increase in parallel with adiposity, as do leptin levels. Thus, insulin fulfils the criteria to be considered as both a satiation and an adiposity signal, as it chronically increases with adiposity and quickly rises after meals (Gerozzisis, 2008).

Insulin and its receptor are widely distributed in the CNS with high concentrations in the hypothalamus, especially the arcuate nucleus, and i.c.v. insulin administration displays powerful anorectic effects. However, brain insulin concentrations are the result of pancreatic insulin transport across the BBB by a saturable transport mechanism (Banks, 2004). Thus, eating increases and fasting decreases the amount of insulin in the CSF and brain (Orosco, et al., 1995), with insulin inducing both short and long term effects on feeding behavior and body weight. Consequently, insulin constitutes a negative feedback mechanism at the level of the CNS, especially the hypothalamus, to report an excess of food intake and energy storage. This hormone acts as an anorexic signal, decreasing food intake and body weight and its administration into the paraventricular mimics these effects, whereas antibodies against insulin injected into the ventral-medial hypothalamus enhance the rate of weight gain. While patients with anorexia nervosa exhibit very low circulating insulin levels, obese patients are hyperinsulinemic (Argente et al, 1997b, 1997c).

Growing evidence suggests that insulin and leptin interact to downregulate ARC production of orexigenic peptides such as NPY and AgRP and, in collaboration with serotonin, enhance POMC production and release (Gerozissis, 2008). Central administration of either glucose or insulin reduces NPY mRNA levels, whereas insulin increases POMC mRNA levels in neurons of the arcuate nucleus (Fekete, et al., 2006). In addition, reduction of food intake after i.c.v. administration of insulin is prevented by the presence of a POMC antagonist (Benoit, et al., 2002), showing that this system is a target for the action of insulin in the control of body weight. Increasing data suggest the possibility that insulin could be another peripheral metabolic signal involved in HPG axis functioning. These data include: 1) the parallel behavior between serum leptin and insulin levels that are positively correlated with the amount of body fat content; 2) the sharing by leptin and insulin of target molecules in the arcuate nucleus of the hypothalamus in charge of energy control and 3) the increase in peripheral insulin resistance and, secondarily, of insulin levels observed in mid-puberty (Ball et al., 2006). Indeed, glucose availability is determinant for gonadotropin secretion as demonstrated by the hypoglycemia induced suppression of LH secretion (Cates and O'Byrne, 2000) and of the 
restoration of $\mathrm{LH}$ secretion after central insulin administration in diabetic rats (Kovacs et al., 2002). However, and independently from its main role as a regulator of glucose levels and utilization, it has also been demonstrated that not only the central infusion of glucose plus insulin, but also the infusion of isolated insulin results in an increase in LH secretion in undernourished animals (Daniel et al., 2000), thus suggesting a possible autonomous role for insulin in HPG axis activity regulation.

Finally, attention has also been recently focused on the eventual role that the amount of food eaten and gastric fill could play in the functioning of the HPG axis. The effects of a less energy dense diet on estrus cycling and the incidence of pregnancy in female hamsters has been analyzed (Szymanski et al., 2009). These experiments showed how the consumption of a diluted diet, which results in a higher bulk intake and a reduction in the net caloric intake and lower insulin levels, induced a lengthening of the estrus cycle, but did not influence the incidence of pregnancy. Thus, these studies suggest that gastric filling and emptying may not influence the functioning of HPG axis, but stress the importance of adequate fuel availability for normal gonadal function.

\section{4) Final remarks}

The long-standing hypothesis that there is integration between the control of energy homeostasis and pubertal onset, pubertal progression and reproductive function was originally proposed due to the observation that nutritional status influenced HPG axis functioning. This hypothesis is now supported by solid scientific evidence as several peptides able to link these functions have been identified. Leptin, the main energy storage signal from adipose tissue, was the pioneer among these peptides and its roles in puberty and reproduction have been thoroughly studied. In addition, ghrelin, the only known orexigenic signal from the digestive tract, has also been discovered to exert a multifaceted influence on the HPG axis, both in its acylated and in its unacylated isoform.

The precise characterization of the mechanisms of action used by these hormones to exert this integrative effect is still far from being achieved. However, their opposite actions on NPY/AgRP and POMC/CART producing neurons in the arcuate nucleus of the hypothalamus as signals either of energy sufficiency (leptin) or insufficiency (ghrelin), and their subsequent role in the stimulation (leptin) and inhibition (ghrelin) of the HPG axis, emphasize these neuropeptides as potential mediators of this integrative function. In addition, recently described signaling circuits, such as the kisspeptin system, which will be extensively reviewed in other articles of this issue, have also been proposed as possible mediators of this coordinated control of energy homeostasis and reproduction.

As the number of identified adipokines and digestive system-derived peptides involved in energy homeostasis control increase, the number of new potential links between energy availability and HPG axis activity also increases. Thus, much research is still required to elucidate the precise role of the different peripheral metabolic signals on the activation and maintenance of the gonadotropic axis and the exact mechanisms mediating these actions. 


\section{5) References}

Ahima, R.S., Prabakaran, D., Mantzoros, C., Qu, D., Lowell, B., Maratos-Flier, E., Flier, J.S., 1996. Role of leptin in the neuroendocrine response to fasting. Nature 382, 250-252.

Ahima, R.S., 2005. Central actions of adipocyte hormones. Trends in Endocrinology and Metabolism 16, 307-313.

Ahmed, M.L., Ong, K.K., Morrell, D.J., Cox, L., Drayer, N., Perry, L., Preece, M.A., Dunger, D.B., 1999. Longitudinal study of leptin concentrations during puberty, Sex differences and relationship to changes in body composition. $J$ Clin Endocrinol Metab 84, 899-905.

Ahmed, M.L., Ong, K.K., Dunger, D.B., 2009. Childhood obesity and the timing of puberty. Trends Endocrinol Metab 20,237-242.

Aksglaede, L., Sorensen, K., Petersen, J.H., Skakkebaek, N.E., Juul, A. 2009, Recent decline in age at breast development: the Copenhagen Puberty Study. Pediatrics. 123, e932-939.

Ankarberg-Lindgren, C., Dahlgren, J., Carlsson, B., Rosberg, S., Carlsson, L., Wikland, K.A., Norjavaara, E. 2001. Leptin levels show diurnal variation throughout puberty in healthy children, and follow a gender-specific pattern. Eur J Endocrinol 145, 43.51.

Argente, J., Barrios, V., Chowen, J.A., Sinha, M.K., Considine, R.V., 1997a. Leptin plasma levels in healthy Spanish children and adolescents, children with obesity, and adolescents with anorexia nervosa and bulimia nervosa. J Pediatr 131, 833-838.

Argente, J., Caballo, N., Barrios, V., Pozo, J., Muñoz, MT., Chowen, JA., Hernández, M., 1997b. Multiple endocrine abnormalities in the growth hormone $(\mathrm{GH})$ and insulin-like growth factor (IGF) axes in prepubertal children with exogenous obesity: Effect of short and long-term restriction caloric diet. J Clin Endocrinol Metab 82:2076-2083.

Argente, J., Caballo, N., Barrios, V., Muñoz, MT., Pozo, J., Chowen, JA., Morandé, G., Hernández, M., 1997c. Multiple endocrine abnormalities in the growth hormone (GH) and insulin-like growth factor (IGF) axes in patients with anorexia nervosa: Effect of a short and long-term weight recuperation. J Clin Endocrinol Metab 82:2084-2092.

Audi, L., Mantzoros, C.S., Vidal-Puig, A., Vargas, D., Gussinye, M., Carrascosa, A. 1998., Leptin in relation to resumption of menses in women with anorexia nervosa. Mol Psychiatry 3, 544-547.

Ball, G.D., Huang, T.T., Gower, B.A., Cruz, M.L., Shaibi, G.Q., Weigensberg, M.J., Goran, M.I., 2006. Longitudinal changes in insulin sensitivity, insulin secretion, and beta-cell function during puberty. J Pediatr 148, 16-22. 
Ballauff, A., Ziegler, A., Emons, G., Sturm, G., Blum, W.F., Remschmidt, H., Hebebrand, J., 1999. Serum leptin and gonadotropin levels in patients with anorexia nervosa during weight gain. Mol Psychiatry 4, 71-75.

Banerjee, R.R., Rangwala, S.M., Shapiro, J.S., Rich, A.S., Rhoades, B., Qi, Y., Wang, J., Rajala, M.W., Pocai, A., Scherer, P.E., Steppan, C.M., Ahima, R.S., Obici, S., Rossetti, L., Lazar, M.A., 2004. Regulation of fasted blood glucose by resistin. Science 303, 1195-1198.

Banks, W.A., 2004. The source of cerebral insulin. European Journal of Pharmacology 490, 5-12.

Banks, W.A., 2008. The blood-brain barrier, connecting the gut and the brain. Regulatory Peptides 149, 11-14.

Barreiro, M.L., Gaytan, F., Castellano, J., Suominen, J.S., Roa, J., Gaytan, M., Aguilar, E., Dieguez, C., Toppari, J., Tena-Sempere, M., 2004. Ghrelin ingibits the proliferative activity of immature Leydig cells in vivo and regulates stem cell factor Messenger ribonucleic acid expression in rat testis. Endocrinology 145, 4825-4834.

Batterham, R.L., Bloom, S.R., 2003a. The gut hormone peptide YY regulates appetite. Annals of the New York Academy of Science, 994, 162-168.

Batterham, R.L., Cohen, M.A., Ellis, S.M., Le Roux, C.W., Withers, D.J., Frost, G.S., Ghatei, M.A., \& Bloom, S.R., 2003b. Inhibition of food intake in obese subjects by peptide YY3-36. The New England Journal of Medicine, 349, 941948.Benoit, S.C., Air, E.L., Coolen, L.M., Strauss, R., Jackman, A., Clegg, D.J., Seeley, R.J., Woods, S.C., 2002. The catabolic action of insulin in the brain is mediated by melanocortins. The Journal of Neuroscience 22, 9048-9052.

Blum, W.F., Englaro, P., Hanitsch, S., Juul, A., Hertel, N.T., Müller, J., Skakkebaek, N.E., Heiman, M.L., Birkett, M., Attanasio, A.M., Kiess, W., Rascher, W., 1997. Plasma leptin levels in healthy children and adolescents, dependence on body mass index, body fat mass, gender, pubertal stage, and testosterone. J Clin Endocrinol Metab 82, 2904-2910.

Böttner, A., Kratzsch, J., Müller, G., Kapellen, T.M., Blüher, S., Keller, E., Blüher, M., Kiess, W., 2004. Gender differences of adiponectin levels develop during the progression of puberty and are related to serum androgen levels. $J$ Clin Endocrinol Metab. 89 ,4053-4061.

Brunetti, L., Orlando, G., Recinella, L., Michelotto, B., Ferrante, C., Vacca, M., 2004. Resistin, but not adiponectin, inhibits dopamine and norepinephrine release in the hypothalamus. Eur J Pharmacol 493, 41-44.

Caminos, J.E., Nogueiras, R., Gaytán,F., Pineda, R., González, C.R., Barreiro, M.L., Castaño, J.P., Malagón, M.M., Pinilla, L., Toppari, J., Diéguez, C., Tena- 
Sempere, M., 2008. Novel expression and direct effects of adiponectin in the rat testis. Endocrinology 149, 3390-3402.

Cates P.S., O'Byrne, K.T., 2000. The area postrema mediates insulin hypoglycaemia-induced suppression of pulsatile LH secretion in the female rat. Brain Res 853, 151-155.

Chabrolle, C., Tosca, L., Dupont, J., 2007. Regulation of adiponectin and its receptors in rat ovary by human chorionic gonadotrophin treatment and potential involvement of adiponectin in granulosa cell steroidogenesis. Reproduction 133, 719-731.

Chan, J.L., Mantzoros, C.S., 2005. Role of leptin in energy-deprivation states, normal human physiology and clinical implications for hypothalamic amenorrhoea and anorexia nervosa. Lancet 366, 74-85.

Chanoine JP., De Waele K., Walia P., 2009. Ghrelin and the growth hormone secretagogue receptor in growth and development.Int J Obes 33 Suppl 1:S4852.

Chartrel, N., Alvear-Perez, R., Leprince, J., Iturrioz, X., Reaux-Le Goazigo, A., Audinot, V., Chomarat, P., Coge, N., Nosjean, O., Rodriguez, M., Galizzi, J.P., Boutin, J.A., Vaudry, H., Llorens-Cortes, C., 2007. Comment on "Obestatin, a peptide encoded by the ghrelin gene, opposes ghrelin's effects on food intake". Science 315, 766.

Chehab, F.F., Lim, M.E., Lu, R., 1996. Correction of the sterility defect in homozygous obese female mice by treatment with the human recombinant leptin. Nat Gen 12,318-320.

Chen, W.P., Witkin, J.W., Silverman, A.J., 1990. Sexual dimorphism in the synaptic input to gonadotropin releasing hormone neurons. Endocrinology 126, 695-702.

Coll, A.P., Challis, B.G., O`Rahilly, S., 2004. Peptide YY3-36 and satiety, clarity or confusion? Endocrinology 145, 2582-2584.

Combs, T.P., Pajvani, U.B., Berg, A.H., Lin, Y., Jelicks, L.A., Laplante, M., Nawrocki, A.R., Rajala, M.W., Parlow, A.F., Cheeseboro, L., Ding, Y.Y., Russell, R.G., Lindemann, D., Hartley, A., Baker, G.R., Obici, S., Deshaies, Y., Ludgate, M., Rossetti, L., Scherer, P.E., 2004. A transgenic mouse with a deletion in the collagenous domain of adiponectin displays elevated circulating adiponectin and improved insulin sensitivity. Endocrinology 145,367-383.

Cummings, D.E., Overduin, J., 2007. Gastrointestinal regulation of food intake. J Clin Invest. 117, 13-23.

Cunningham, M.J., Clifton, D.K., Steiner, R.A., 1999. Leptin's actions on the reproductive axis, perspectives and mechanisms. Biol. Reprod. 60, 616-622. 
Daniel, J.A., Thomas, M.G., Hale, C.S., Simmons, J.M., Keisler, D.H., 2000. Effect of cerebroventricular infusion of insulin and (or) glucose on hypothalamic expression of leptin receptor and pituitary secretion of $\mathrm{LH}$ in diet-restricted ewes.Domest Anim Endocrinol 18, 177-185.

Demerath, E.W., Towne, B., Wisemandle, W., Blangero, J., Chumlea, W.C., Siervogel, R.M., 1999. Serum leptin concentration, body composition, and gonadal hormones during puberty. Int J Obes Relat Metab Disord 23, 678-685.

Falorni, A., Bini, V., Molinari, D., Papi, F., Celi, F., Di Stefano, G., Berioli, M.G., Bacosi, M.L., Contessa, G., 1997. Leptin serum levels in normal weight and obese children and adolescents, relationship with age, sex, pubertal development, body mass index and insulin. Int J Obes Relat Metab Disord 21, 881-890.

Farooqi, I.S., Jebb, S.A., Langmack, G., Lawrence, E., Cheetham, C.H., Prentice, A.M., Hughes, I.A., McCamish, M.A., O'Rahilly, S., 1999. Effects of recombinant leptin therapy in a child with congenital leptin deficiency. $\mathrm{N}$ Engl $\mathrm{J}$ Med 341, 879-84.

Farooqi, I.S., Wangensteen, T., Collins, S., Kimber, W., Matarese, G., Keogh, J.M., Lank, E., Bottomley, B., Lopez-Fernandez, J., Ferraz-Amaro, I., Dattani, M.T., Ercan, O., Myhre, A.G., Retterstol, L., Stanhope, R., Edge, J.A., McKenzie, S., Lessan, N., Ghodsi, M., De Rosa, V., Perna, F., Fontana, S, Barroso, I., Undlien, D.E., O'Rahilly, S., 2007. Clinical and molecular genetic spectrum of congenital deficiency of the leptin receptor. N Engl J Med 356, 237247.

Fekete, C., Singru, P.S., Sánchez, E., Sarkar, S., Christoffolete, M.A., Riberio, R.S., Rand, W.M., Emerson, C.H., Bianco, A.C., Lechan, R.M., 2006.

Differential effects of central leptin, insulin, or glucose administration during fasting on the hypothalamic-pituitary-thyroid axis and feeding-related neurons in the arcuate nucleus. Endocrinology 147, 520-529.

Fernandez-Fernandez, R., Navarro, V. M., Barreiro, M. L., Vigo, E. M., Tovar, S., Sirotkin, A. V., Casanueva, F. F., Aguilar, E., Dieguez, C., Pinilla, L., TenaSempere, M., 2005a. Effects of chronic hyperghrelinemia on puberty onset and pregnancy outcome in the rat. Endocrinology 146, 3018-3025.

Fernández-Fernández, R., Tena-Sempere, M., Navarro, V. M., Barreiro, M. L., Castellano, J. M., Aguilar, E., Pinilla, L., 2005b. Effects of ghrelin upon gonadotropin-releasing hormone and gonadotropin secretion in adult female rats, In vivo and in vitro studies. Neuroendocrinology 82, 245-255.

Fernández-Fernández, R., Aguilar, E., Tena-Sempere, M., Pinilla, L., 2005c. Effects of polypeptide YY3-36 upon luteinizing hormone-releasing hormone and gonadotropin secretion in prepubertal rats, in vivo and in vitro studies. Endocrinology 146, 1403-1410. 
Fernández-Fernández, R., Martini, A. C., Navarro, V. M., Castellano, J. M., Dieguez, C., Aguilar, E., Pinilla, L., Tena-Sempere, M., 2006. Novel signals for the integration of energy balance and reproduction. Mol Cell Endocrinol 254$255,127-132$.

Fombonne, J., Charrier, C., Goddard, I., Moyse, E., Krantic, S., 2007. Leptinmediated decrease of cyclin A2 and increase of cyclin D1 expression. Relevance for the control of prepubertal rat leydig cell division and differentiation. Endocrinology 148, 2126-2137.

Frisch, R.E., McArthur, J.W., 1974. Menstrual cycles, fatness as a determinant of minimum weight for height necessary for their maintenance or onset. Science 185, 949-951.

García de Alvaro, M.T., Muñoz-Calvo, M.T., Barrios, V., Martínez, G., MartosMoreno, G.A., Hawkins, F., Argente, J., 2007. Regional fat distribution in adolescents with anorexia nervosa: effect of duration of malnutrition and weight recovery. Eur J Endocrinol 157, 473-479.

Garcia-Mayor, R.V., Andrade, M.A., Rios, M., Lage, M., Dieguez, C., Casanueva, F.F., 1997. Serum leptin levels in normal children, relationship to age, gender, body mass index, pituitary-gonadal hormones, and pubertal stage. $\mathrm{J}$ Clin Endocrinol Metab 82, 2849-2855.

Gardiner, J.V., Jayasena, C.N., Bloom, S.R., 2008. Gut hormones, a weight off your mind. Journal of Neuroendocrinology 20, 834-841.

Gaytan, F., Morales, C., Barreiro, M.L., Jeffery, P., Chopin, L.K., Herington, A.C., Casanueva, F.F., Aguilar, E., Dieguez, C., Tena-Sempere, M., 2005. Experssion of growth hormone secretagogue receptor type 1a, the functional Ghrelin receptor, in human ovarian surface epithelium, mullerian duct derivatives and ovarian tumors. J Clin Endocrinol Metab 90,1798-1804.

Gerozissis, K., 2008. Brain insulin, energy and glucose homeostasis; genes, environment and metabolic pathologies. European Journal of Pharmacology $585,38-49$.

Gluckman, P.K., Hanson, M.A., 2006. Evolution, development and timing of puberty. Trends in Endocrinology \& Metabolism 17, 7-12.

Greenman, Y., Rouach, V., Limor, R., Gilad, S., Stern, L., 2009. Testosterone is a strong correlate of ghrelin levels in men and postmenopausal women. Neuroendocrinology 89, 79-85.

Gueorguiev, M., Góth, M.L., Korbonits, M., 2001. Leptin and puberty, a review. Pituitary 4,79-86.

Haqq, A.M., Grambow, S.C., Muehlbauer, M., Newgard, C.B., Svetkey, L.P., Carrel, A.L., Yanovski, J.A., Purnell, J.Q., Freemark, M., 2008. Ghrelin 
concentrations in Prader-Willi syndrome (PWS) infants and children, changes during development. Clin Endocrinol (Oxf) 69, 911-920.

Herrid, M., O'Shea, T., McFarlane, J.R. 2008. Ontogeny of leptin and its receptor expressin mouse testis during the postnatal period. Mol Reprod Dev. $75,874-880$.

Herpertz-Dahlmann, B., 2009. Adolescent eating disorders: definitions, symptomatology, epidemiology and comorbidity. Child Adolesc Psychiatr Clin N Am 18, 31-47.

Howard, A.D., Feighner SD, Cully DF, Arena JP, Liberator PA, Rosenblum CI, Hamelin M, Hreniuk DL, Palyha OC, Anderson J, Paress PS, Diaz C, Chou M, Liu KK, McKee KK, Pong SS, Chaung LY, Elbrecht A, Dashkevicz M, Heavens R, Rigby M, Sirinathsinghji DJ, Dean DC, Melillo DG, Patchett AA, Nargund R, Griffin PR, DeMartino JA, Gupta SK, Schaeffer JM, Smith RG, Van der Ploeg $\mathrm{LH}$. 1996. A receptor in pituitary and hypothalamus that functions in growth hormone release. Science. 273:974-977.

Hoyda, T.D., Samson, W.K., Ferguson, A.V., 2009. Adiponectin Depolarizes Parvocellular Paraventricular Nucleus Neurons Controlling Neuroendocrine and Autonomic Function. Endocrinology 150, 832 - 840.

Jin, L., Burguera, B.G., Couce, M.E., Scheithauer, B.W., Lamsan, J., Eberhardt, N.L., Kulig, E., Lloyd, R.V., 1999 Leptin and leptin receptor expression in normal and neoplastic human pituitary, evidence of a regulatory role for leptin on pituitary cell proliferation. J Clin Endocrinol Metab 84, 2903-2911.

Kaplowitz, P.B., 2008. Link Between Body Fat and the Timing of Puberty. Pediatrics 121;S208-S217.

Kennedy, G.C., Mitra, J., 1963. Body weight and food intake as initiating factors for puberty in the rat. J. Physiol. 166, 408-418.

Kershaw, E.E., Flier, J.S., 2004. Adipose tissue as an endocrine organ. J Clin Endocrinol Metab. 89, 2548-2556.

Kojima, M., Hosoda, H., Date, Y., Nakazato, M., Matsuo, H., Kangawa, K., 1999. Ghrelin is a growth-hormone-releasing acylated peptide from stomach. Nature 402, 656-660.

Kolaczynski, J.W., Ohannesian, J.P., Considine, R.V., Marco, C.C., Caro, J.F., 1996. Response of leptin to short-term and prolonged overfeeding in humans. J Clin Endocrinol Metab 81; 4162-4165.

Korbonits, M., Goldstone, A.P., Gueorguiev, M., Grossman, A.B., 2004.

Ghrelin-a hormone with multiple functions. Front. Neuroendocrinol 25, 27-68. 
Korner, A., Kratzsch, J., Kiess, W., 2005 Adipocytokines, leptin--the classical., resistin--the controversical., adiponectin--the promising, and more to come. Best Pract Res Clin Endocrinol Metab 19, 525-546.

Kovacs. P., Parlow, A.F., Karkanias, G.B., 2002. Effect of centrally administered insulin on gonadotropin-releasing hormone neuron activity and luteinizing hormone surge in the diabetic female rat. Neuroendocrinology 76, 357-365.

Kratzsch, J., Lammert, A., Bottner, A., Seidel, B., Mueller, G., Thiery, J., 2002. Circulating soluble leptin receptor and free leptin index during childhood, puberty, and adolescence. J Clin Endocrinol Metab 87, 4587-4594.

Kubota, N., Terauchi, Y., Yamauchi, T., Kubota, T., Moroi, M., Matsui, J., Eto, K., Yamashita, T., Kamon, J., Satoh, H., Yano, W., Froguel, P., Nagai, R., Kimura, S., Kadowaki, T., Noda, T., 2002. Disruption of adiponectin causes insulin resistance and neointimal formation. Journal of Biological Chemistry 277, 25863-25866.

Landt, M., Gingerich, R.L., Havel, P.J., Mueller, W.M., Schoner, B., Hale, J.E., Heiman, M.L., 1998. Radioimmunoassay of rat leptin: sexual dimorphism reversed from humans. Clin Chem 44, 565-570.

Lanfranco, F., Bonelli, L., Baldi, M., Me, E., Broglio, F., Ghigo, E. 2008., Acylated ghrelin inhibits spontaneous luteinizing hormone pulsatility and responsiveness to naloxone but not that to gonadotropin-releasing hormone in young men, evidence for a central inhibitory action of ghrelin on the gonadal axis. J Clin Endocrinol Metab 93, 3633-3639.

Lebrethon, M.C., Vandersmissen, E., Gerard, A., Parent, A.S., Junien, J.L., Bourguignon, J.P., 2000a. In vitro stimulation of the prepubertal rat gonadotropin-releasing-hormone pulse generator by leptin and neuropeptide $Y$ through distinct mechanisms. Endocrinology 141, 1464-1469. (a)

Lebrethon, M.C., Vandersmissen, E., Gerard, A., Parent, A.S., Bourguignon, J.P., 2000b. Cocaine and amphetamine-regulated-transcript peptide mediation of leptin stimulatory effect on the rat gonadotropin-releasing hormone pulse generator in vitro. J Neuroendocrinol 12, 383-385. (b)

le Roux, C.W., Batterham, R.L., Aylwin, S.J., Patterson, M., Borg, C.M., Wynne, K.J., Kent, A., Vincent, R.P., Gardiner, J., Ghatei, M.A., \& Bloom, S.R., 2006. Attenuated peptide $Y Y$ release in obese subjects is associated with reduced satiety. Endocrinology, 147, 3-8.

Liu, J., Prudom, C.E., Nass, R., Pezzoli, S.S., Oliveri, M.C., Johnson, M.L., Veldhuis, P., Gordon, D.A., Howard, A.D., Witcher, D.R., Geysen, H.M., Gaylinn, B.D., Throner, M.O., 2008. Novel ghrelin assays provide evidence for independent regulation of ghrelin acylation and secretion in healthy young men. J Clin Endocrinol Metab 93, 1980-1987. 
Lorenzi, T., Meli, R., Marzioni, D., Morroni, M., Baragli, A., Castellucci, M., Gualillo, O., Muccioli, G., 2009. Ghrelin, a metabolic signal affecting the reproductive system. Cytokine Growth Factor Rev 20, 137-152.

Ma, K., Cabrero, A., Saha, P.K., Kojima, H., Li, L., Chang, B.H., Paul, A., Chan, L., 2002. Increased beta -oxidation but no insulin resistance or glucose intolerance in mice lacking adiponectin. Journal of Biological Chemistry 277, 34658-34661.

Maeda, N., Shimomura, I., Kishida, K., Nishizawa, H., Matsuda, M., Nagaretani, H., Furuyama, N., Kondo, H., Takahashi, M., Arita, Y., Komuro, R., Ouchi, N., Kihara, S., Tochino, Y., Okutomi, K., Horie, M., Takeda, S., Aoyama, T., Funahashi, T., Matsuzawa, Y., 2002. Diet-induced insulin resistance in mice lacking adiponectin/ACRP30. Nat Med 8, 731-737.

Maffei, M., Halaas, J., Ravussin, E., Pratley, R.E., Lee, G.H., Zhang, Y., Fei, H., Kim, S., Lallone, R., Ranganathan S., 1995 Leptin levels in human and rodent, measurement of plasma leptin and ob RNA in obese and weight-reduced subjects. Nat Med. 1, 1155-1161.

Magni, P., Vettor, R., Pagano, C., Calcagno, A., Beretta, E., Messi, E., Zanisi, M., Martini, L., Motta, M., 1999. Expression of a leptin receptor in immortalized gonadotropin-releasing hormonesecreting neurons. Endocrinology 140, 15811585.

Mantzoros, C.S., Flier, J.S., Rogol, A.D., 1997. A longitudinal assessment of hormonal and physical alterations during normal puberty in boys. V. Rising leptin levels may signal the onset of puberty. J Clin Endocrinol Metab 82, 10661070.

Martini, A.C., Fernández-Fernández, R., Tovar, S., Navarro, V.M., Vigo, E., Vazquez, M.J., Davies, J.S., Thompson, N.M., Aguilar, E., Pinilla, L., Wells, T., Dieguez, C., Tena-Sempere, M., 2006. Comparative analysis of the effects of ghrelin and unacylated ghrelin on luteinizing hormone secretion in male rats. Endocrinology 147, 2374-2382.

Martos-Moreno, G.Á., Barrios, V., Argente, J., 2006. Normative data for adiponectin, resistin, interleukin 6 , and leptin/receptor ratio in a healthy Spanish pediatric population, relationship with sex steroids. Eur J Endocrinol 155, 429434.

Meier, U., Gressner, A.M., 2004. Endocrine regulation of energy metabolism, review of pathobiochemical and clinical chemical aspects of leptin, ghrelin, adiponectin, and resistin. Clin Chem. 50, 1511-1525.

Merchenthaler, I., 1998. LHRH and sexual dimorphism. Ann NY Acad Sci 863, 175-187.

Mericq, V., 2006. Low birth weight and endocrine dysfunction in postnatal life. Pediatr Endocrinol Rev 4, 3-14. 
Misra, M., Miller, K.K., Almazan, C., Ramaswamy, K., Aggarwal., A., Herzog, D.B., Neubauer, G., Breu, J., Klibanski, A., 2004. Hormonal and body composition predictors of soluble leptin receptor, leptin, and free leptin index in adolescent girls with anorexia nervosa and controls and relation to insulin sensitivity. J Clin Endocrinol Metab 89, 3486-3495.

Mitchell, M., Armstrong, D.T., Robker, R.L., Norman, R.J. 2005. Adipokines, implications for female fertility and obesity. Reproduction 130, 583-597. Murphy, K.G., Dhillo, W.S., Bloom, S.R., 2006. Gut peptides in the regulation of food intake and energy homeostasis. Endocrine Reviews 27, 719-727.

Muñoz, MT., Argente, J. 2002. Anorexia nervosa in female adolescents: endocrine and bone mineral density abnormalities. Eur J Endocrinol 147:275286.

Muñoz, MT., De la Piedra, C., Barrios, V., Garrido, G., Argente, J. 2004. Changes in bone density and bone markers in rhythmic gymnasts and ballet dancers: Implications of puberty and leptin level. Eur J Endocrinol 151:491-496.

Murphy, K.G., Dhillo, W.S., Bloom, S.R., 2006. Gut peptides in the regulation of food intake and energy homeostasis. Endocr Rev 27, 719-727.

Nagatani, S., Guthikonda, P., Foster, D.L., 2000. Appearance of a nocturnal peak of leptin secretion in the pubertal rat. Horm Behav 37, 345-352.

Nogueiras, R., Barreiro, M.I:, Caminos, J.E., Gaytán, F., Suominen, J.S., Navarro, V.M., Casanueva, F.F., Aguilar, E., Toppari, J., Diéguez, C., TenaSempere, M., 2004.Novel expression of resistin in rat testis: functional role and regulation by nutritional status and hormonal factors. J Cell Sci 117:3247-3257.

Nonaka, N., Shioda, S., Niehoff, M.L., \& Banks, W.A., 2003. Characterization of blood-brain barrier permeability to PYY3-36 in the mouse. Journal of Pharmacology and Experimental Therapeutics, 306, 948-953.

Norman, R.J., Clark, A.M., 1998. Obesity and reproductive disorders, A review. Reprod Fertil Dev 10, 55-63.

Nunez-de la Mora, A., Chatterton, R.T., Choudhury, O.A., Napolitano, D.A., Bently, G.R. 2007. Childhood conditions influence adult progesterone levels. PLoS Med 4, e167.

Orosco, M., Gerozissis, K., Rouch, C., Nicolaïdis, S., 1995. Feeding-related immunoreactive insulin changes in the $\mathrm{PVN}-\mathrm{VMH}$ revealed by microdialysis. Brain Research 671, 149-158.

Pantel, J.,Legendre, M., Cabrol, S., Hilal, L., Hajaji, Y., Morisset, S., Nivot, S., Vie-Luton, MP., Grouselle, D., de Kerdanet, D., Kadiri, A., Epelbaum, J., Le Bouc, Y., Amselem, S., 2006. Loss of constitutive activity of the growth 
hormone secretagogue receptor in familial short stature. J Clin Invest 116, 760 768.

Pinilla, L., Fernandez-Fernandez, R., Vigo, E., Navarro, V.M., Roa, J., Castellano, J.M., Pineda, R., Tena-Sempere, M., Aguilar, E., 2006. The stimulatory effect of PYY3-36 on gonadotropin secretion is potentiated in fasted rats. Am. J. Physiol. Endocrinol. Metab. 270, E1162-E1171.

Plant, T.M., Shahab, M., 2002. Neuroendocrine mechanisms that delay and initiate puberty in higher primates. Physiol Behav 77, 717-722.

Pravenec, M., Kazdova, L., Landa, V., Zidek, V., Mlejnek, P., Jansa, P., Wang, J., Qi, N., Kurtz, T.W., 2003. Transgenic and recombinant resistin impair skeletal muscle glucose metabolism in the spontaneously hypertensive rat. Journal of Biological Chemistry 278, 45209-45215.

Quinton, N.D., Smith, R.F., Clayton, P.E., Gill, M.S., Shalet, S., Justice, S.K., Simon, S.A., Walters, S., Postel-Vinay, M.C., Blakemore, A.I., Ross, R.J., 1999. Leptin binding activity changes with age, the link between leptin and puberty. $J$ Clin Endocrinol Metab 84, 2336-2341.

Rangwala, S.M., Rich, A.S., Rhoades, B., Shapiro, J.S., Obici, S., Rossetti, L.,Lazar, M.A., 2004. Abnormal glucose homeostasis due to chronic hyperresistinemia. Diabetes 53, 1937-1941.

Senay, A., Mithat, B., Alpaslan, T., Ebru, K., Deniz, G., 2009. Serum resistin and adiponectin levels in youn non-obese women with polycystic ovary syndrome. Gynecol Endocrinol 15: 1-6.

Sinha, M.K., Ohannesian, J.P., Heiman, M.L., Kriauciunas, A., Stephens, T.W., Magosin, S., Marco, C., Caro, J.F., 1996. Nocturnal rise of leptin in lean, obese, and non-insulin-dependent diabetes mellitus subjects. J Clin Invest 97, 13441347.

Sloboda, D.M., Howie, G.J., Pleasants, A., Gluckman, P.D., Vickers, M.H., 2009. Pre- and postnatal nutritional histories influence reproductive maturation and ovarian function in the rat. PLoS one 4, e6744.

Smith, J.T., Mark, P.J., Waddell, B.J., 2005. Developmental increases in plasma leptin binging activity and tissue Ob-RemRNA expression in the rat. $\mathrm{J}$ Endocrinol 184, 535-541.

Smith, J.T., Achohido, B.V., Clifton, D.K., Steiner, R.A., 2006. Kiss-1 neurones are direct targets for leptin in the ob/ob mouse. J Neuroendocrinol 18, 298-303.

Smith, R.G., Van der Ploeg LH, Howard AD, Feighner SD, Cheng K, Hickey GJ, Wyvratt MJ Jr, Fisher MH, Nargund RP, Patchett AA.. 1997. Peptidomimetic regulation of growth hormone secretion. Endocr. Rev. 18:621-645.

Sone, M., Osamura, R.Y., 2001. Leptin and the pituitary. Pituitary 4, 15-23. 
Sorensen, K., Aksglaede, L., Petersen, J.H., Juul, A., 2009. Recent changes in pubertal timing in healthy Danish boys: Associations with body mass index. $J$ clin Endocrinol Metab (ahead of print: jc.2009-1478v1)

Soriano-Guillén, L., Barrios, V., Campos-Barros, A., Argente, J., 2004a. Ghrelin levels in obesity and anorexia nervosa, effect of weight reduction or recuperation. Journal of Pediatrics 144, 36-42.

Soriano-Guillén, L., Barrios, V., Chowen, J.A., Sanchez, I., Vila, S., Quero, J., Argente, J., 2004b. Ghrelin levels from fetal life through early adulthood, relationship with endocrine and metabolic and anthropometric measures. Journal of Pediatrics 144, 30-35.

Szymanski, L.A., Tabaac, B.J., Schneider, J.E., 2009. Signals that link energy to reproduction, gastric fill, bulk intake, or caloric intake? Physiol Behav 96, 540547.

Tena-Sempere, M., Pinilla, L., González, L.C., Diéguez, C., Casanueva, F.F., Aguilar, E., 1999 Leptin inhibits testosterone secretion from adult rat testis in vitro. J Endocrinol 161, 211-218.

Tena-Sempere, M., Manna, P.R., Zhang, F.P., Pinilla, L., González, L.C., Diéguez, C., Huhtaniemi, I., Aguilar, E., 2001a. Molecular mechanisms of leptin action in adult rat testis: potential targets for leptin-induced inhibition of steroidogenesis and patter of leptin receptor messenger ribonucleic acid expression. J Endocrinol 170, 413-423.

Tena-Sempere M., Pinilla, L., Zhang, F-P., González, L.D., Huhtaniemi, I., Casanueva, F.F., Dieguez, C., Aguilar, E. 2001 Developmental and hormonal regulation of leptin receptor $(\mathrm{Ob}-\mathrm{R})$ messenger ribonucleic acid expression in rat testis. Biol of Reprod 64, 634-643.

Tena-Sempere, M., Barreiro, M. L., 2002. Leptin in male reproduction, The testis paradigm. Mol Cell Endocrinol 188, 9-13.

Tena-Sempere M., 2008. Ghrelin and reproduction, ghrelin as novel regulator of the gonadotropic axis. Vitam Horm 77, 285-300.

Toulis, K.A., Goulis, D.G., Farmakiotis, D., Georgopoulos, N.A., Katsikis, I., Tarlatzis, B.C., Papadimas, I., Panidis, D., 2009. Adiponectin levels in women with polycystic ovary syndrome: a systematic review and a meta-analysis. Hum Reprod Update 15: 297-307.

Toshinai, K., Yamaguchi, H., Sun, Y., Smith, R.G., Yamanaka, A., Sakurai, T., Date, Y., Mondal., M.S., Shimbara, T., Kawagoe, T., Murakami, N., Miyazato, M., Kangawa, K., Nakazato, M., 2006. Des-acyl ghrelin induces food intake by a mechanism independent of the growth hormone secretagogue receptor. Endocrinology 147, 2306-2314. 
van der Lely, A. J., Tschop, M., Heiman, M. L., and Ghigo, E., 2004. Biological., physiological., pathophysiological., and pharmacological aspects of ghrelin. Endocr Rev 25, 426-457.

van der Sluis IM, de Ridder MA, Boot AM, Krenning EP, de Muinck KeizerSchrama SM., 2002. Reference data for bone density and body composition measured with dual energy $X$ ray absorptiometry in white children and young adults.Arch Dis Child 87, 341-347.

Viani, I., Vottero, A., Tassi, F., Cremonini, G., Sartori, C., Bernasconi, S.,Ferrari, B., Ghizzoni, L., 2008. Ghrelin inhibits steroid biosynthesis by cultured granulosa-lutein cells. J Clin Endocrinol Metab 93, 1476-1481.

Vickers, M.H., Gluckman, P.D., Conveny, A.H., Hofman, P.L., Cutfield, W.S., Gertler, A., Breier, B.H., Harris, H. 2005. Neonatal leptin treatment reverses developmental programming. Endocrinology 146, 4211-4216.

Vulliémoz, N.R., Xiao, E., Xia-Zhang, L., Wardlaw, S.L., Ferin, M., 2005. Central infusion of agouti-related peptide suppresses pulsatile luteinizing hormone release in the ovariectomized rhesus monkey. Endocrinology 146, 784-789.

Wells, J.C., 2007. Sexual dimorphism of body composition. Best Pract Res Clin Endocrinol Metab 21,415-430.

Welt, C.K., Chan, J.L., Bullen, J., Murphy, R., Smith, P., DePaoli, A.M., Karalis, A., Mantzoros, C.S., 2004. Recombinant human leptin in women with hypothalamic amenorrhea. N Engl J Med. 351, 987-997.

Wilkinson, M., Wilkinson, D., Wiesner, G., Morash, B., Ur, E., 2005. Hypothalamic resistin immunoreactivity is reduced by obesity in the mouse, colocalization with alpha-melanostimulating hormone. Neuroendocrinology 81, 1930.

Woods, S.C., D'Alessio, D.A., 2008. Central control of body weight and appetite. J Clin Endocrinol Metab 93, S37-S50.

Wynne, K., Stanley S., McGowan, B., Bloom, S., 2005. Appetite control. The Journal of Endocrinology 184, 291-318.

Yildiz, B.O., Suchard, M.A., Wong, M-L., McCann, S.M., Licinio, J. 2004. Alterations in the dynamics of circulating ghrelin, adiponectin, and leptin in human obesity. Proc Natl Acad Sci USA 110, 10434-10439.

Yilmaz, M., Bukan, N., Demirci, H., Oztürk, C., Kan, E., Ayvaz, G., Arslan, M., 2009. Serum resistin and adiponectin levels in women with polycystic ovary syndrome. Gynecol Endocrinol 25, 246-252.

Yu, W.H., Kimura, M., Walczewska, A., Karanth, S., McCann, S.M., 1997. Role of leptin in hypothalamic-pituitary function. Proc Natl Acad Sci USA 94, 10231028. 
Yura, S., Ogawa, Y., Sagawa, N., Masuzaki, H., Itoh, H., Ebihara, K., AizawaAbe, M., Fujii, S., Nakao, K., 2000. Accelerated puberty and late-onset hypothalamic hypogonadism in female transgenic skinny mice. J Clin Invest 105, 749-755.

Zhang, Y., Proenca, R., Maffei, M., Barone, M., Leopold, L., Friedman, J.M., 1994. Positional cloning of the mouse obese gene and its human homologue. Nature 372, 425-432.

Zhang, J.V., Ren, P.G., Avsian-Kretchmer, O., Luo, C.W., Rauch, R., Klein, C., Hsueh, A.J., 2005. Obestatin, a peptide encoded by the ghrelin gene, opposes ghrelin's effects on food intake. Science 310, 996-999. 


\section{6) Figure legends}

Figure 1. Schematic representation of potential factors implicated in human pubertal onset.

Figure 2. Ontogeny of the hypothalamic-pituitary-gonadal axis in humans.

Figure 3. Schematic representation of the onset of pubertal development in human males and females.

Figure 4. A) Mean circulating leptin concentrations throughout pubertal development in both male and female children and adolescents divided according to Tanner stages. B) There is a significant correlation between body mass index (BMI) and circulating leptin levels (modified from Argente et al., 1997a),

Figure 5. Mean circulating leptin concentrations in patients with anorexia nervosa at the moment of diagnosis and after a $10 \%$ ponderal recuperation (PR) compared to normal adolescent females (Tanner V) (modified from Argente et al., 1997a).

Figure 6. Mean circulating leptin concentrations in prepubertal patients with exogenous obesity at the moment of diagnosis and after a reduction in body mass index (BMI)-standard deviation (SDS) of approximately 50\% (modified from Argente et al., 1997a): 
Possible factors implicated in human pubertal onset

- Age (bone age)

- Sex

- Race

- Inheritance

- Timing

- Nutrition

- Stress

- Body mass

- Body fat

- Geographical factors

- Sex steroids

- Adrenarche

- Cerebral lesions

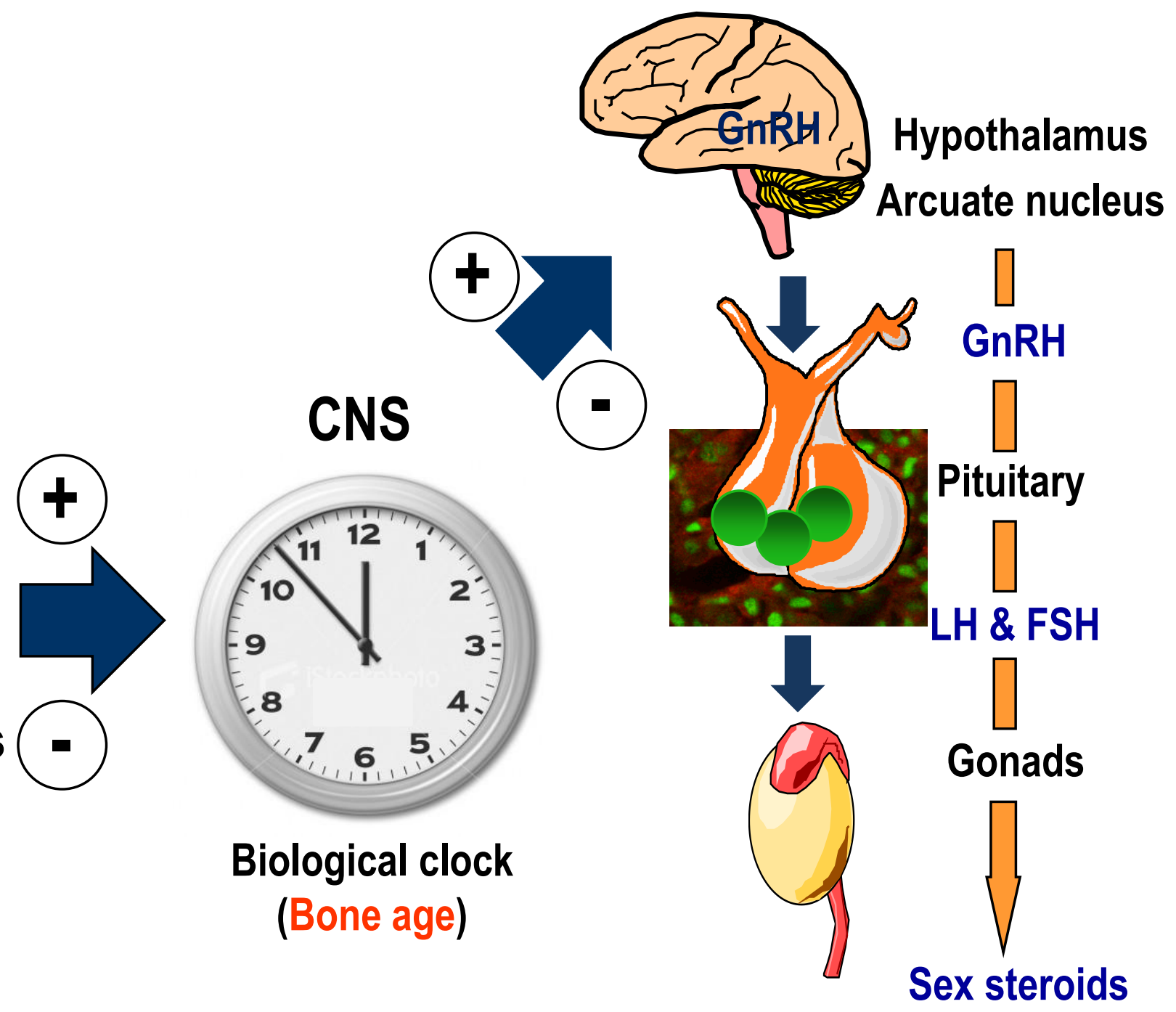

Figure 1 


\section{Ontogeny of the hypothalamic-pituitary-gonadal axis in humans}

\section{GnRH Neurones}

(4.5 weeks)

Olfactory placode

Gonadotrophs

-LH /FSH in pituitary: 10 weeks -Response to GnRH: 11-12 weeks

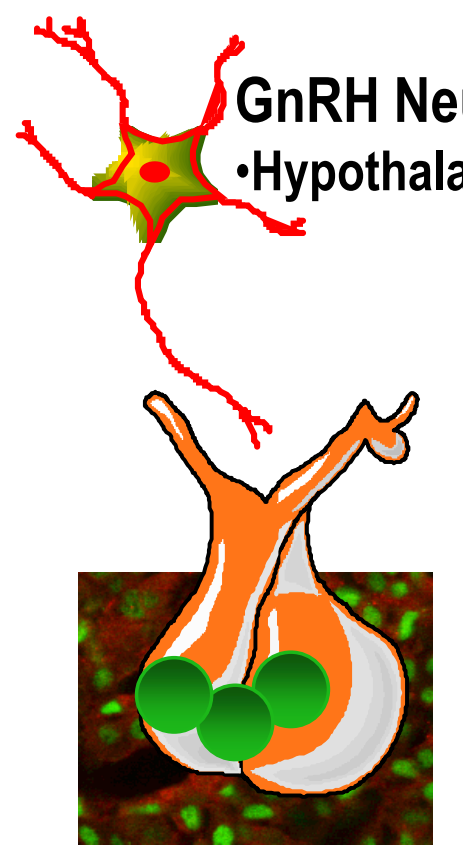

LH \& FSH

(LH /FSH in plasma: 11-12 weeks)

FETAL PERIOD

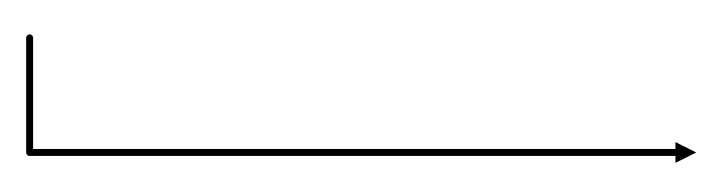

of $\mathrm{GnRH}$

(>20 weeks)

Gonad

Figure 2 


\section{Onset of pubertal development in human males \& females}

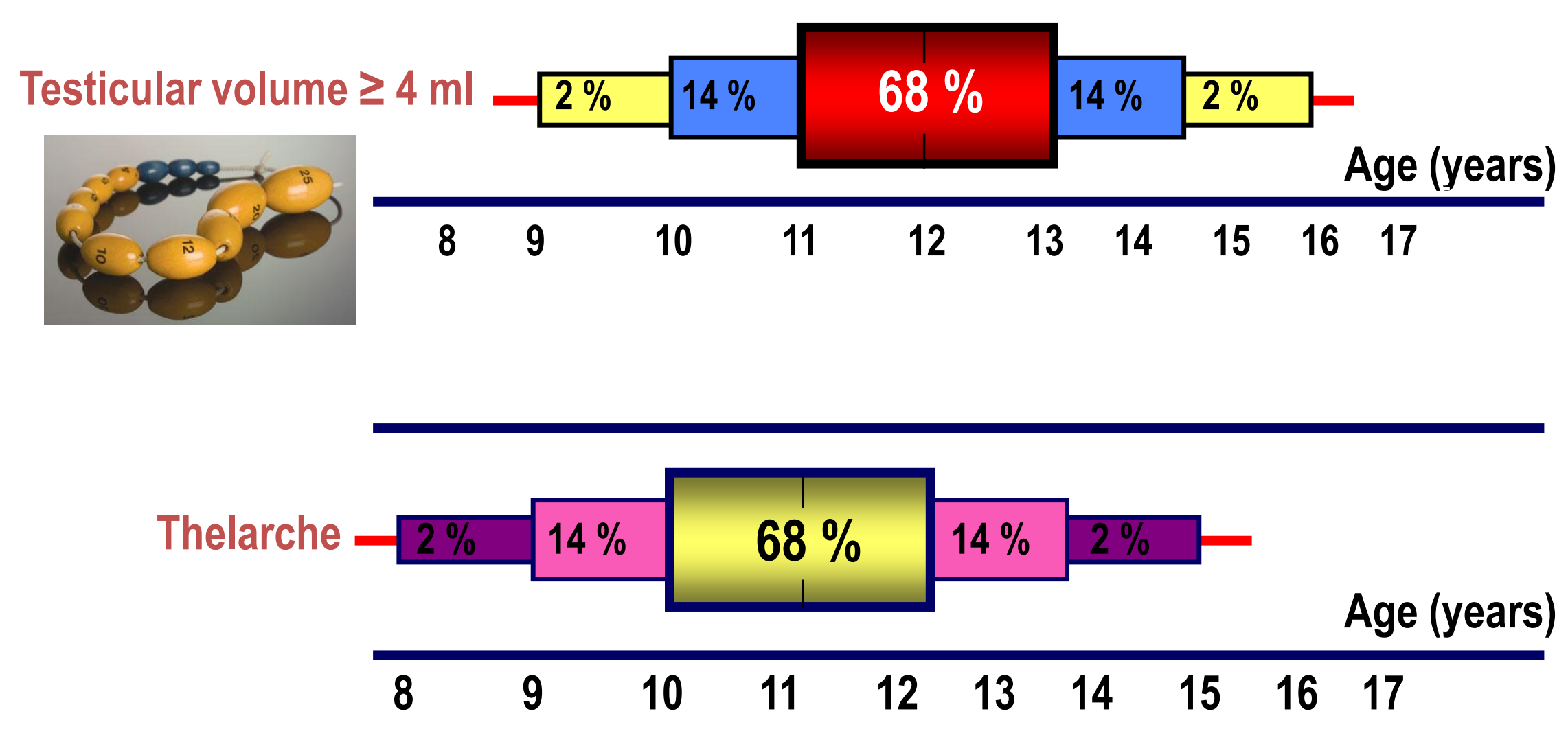

Figure 3 


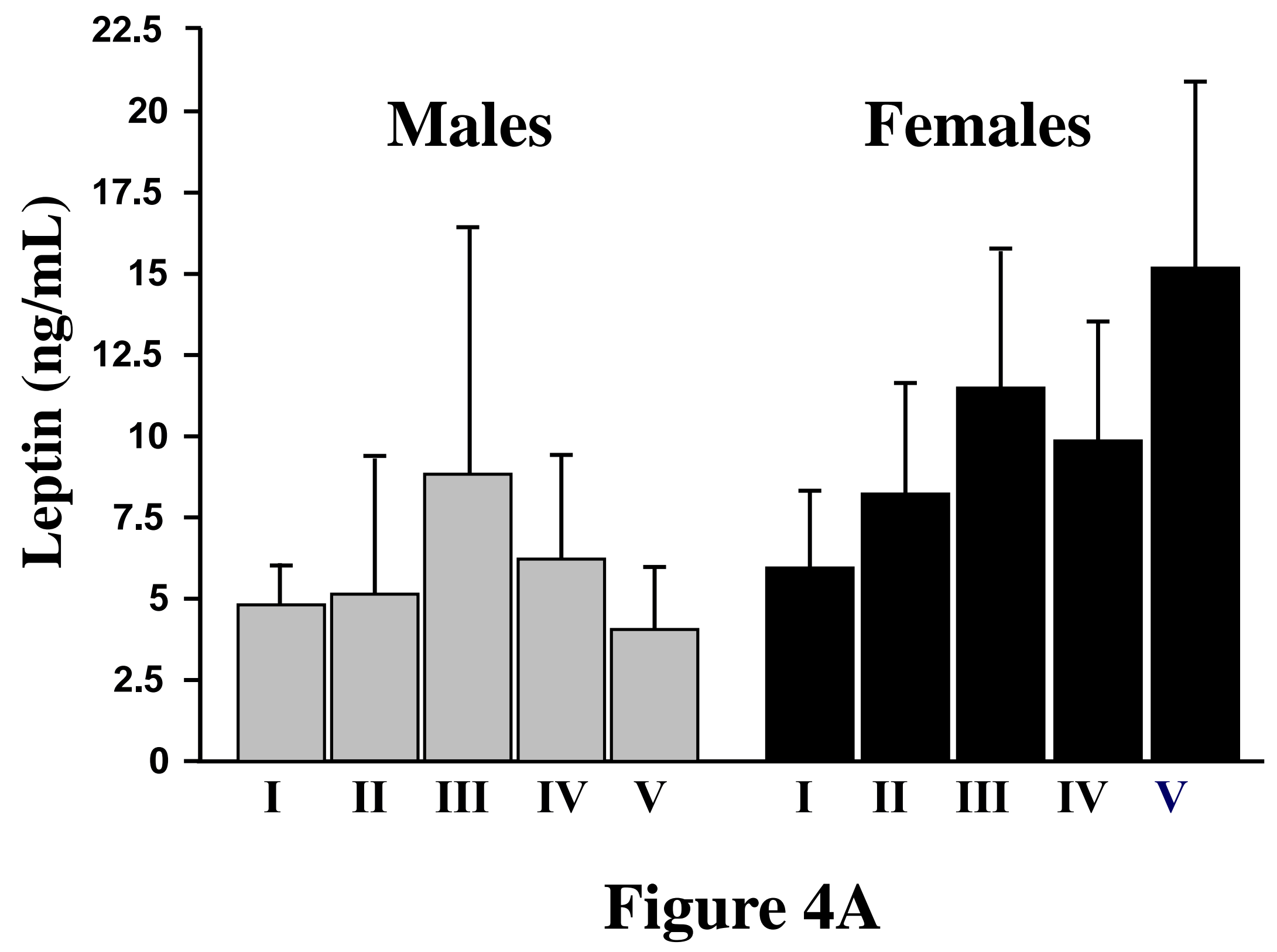




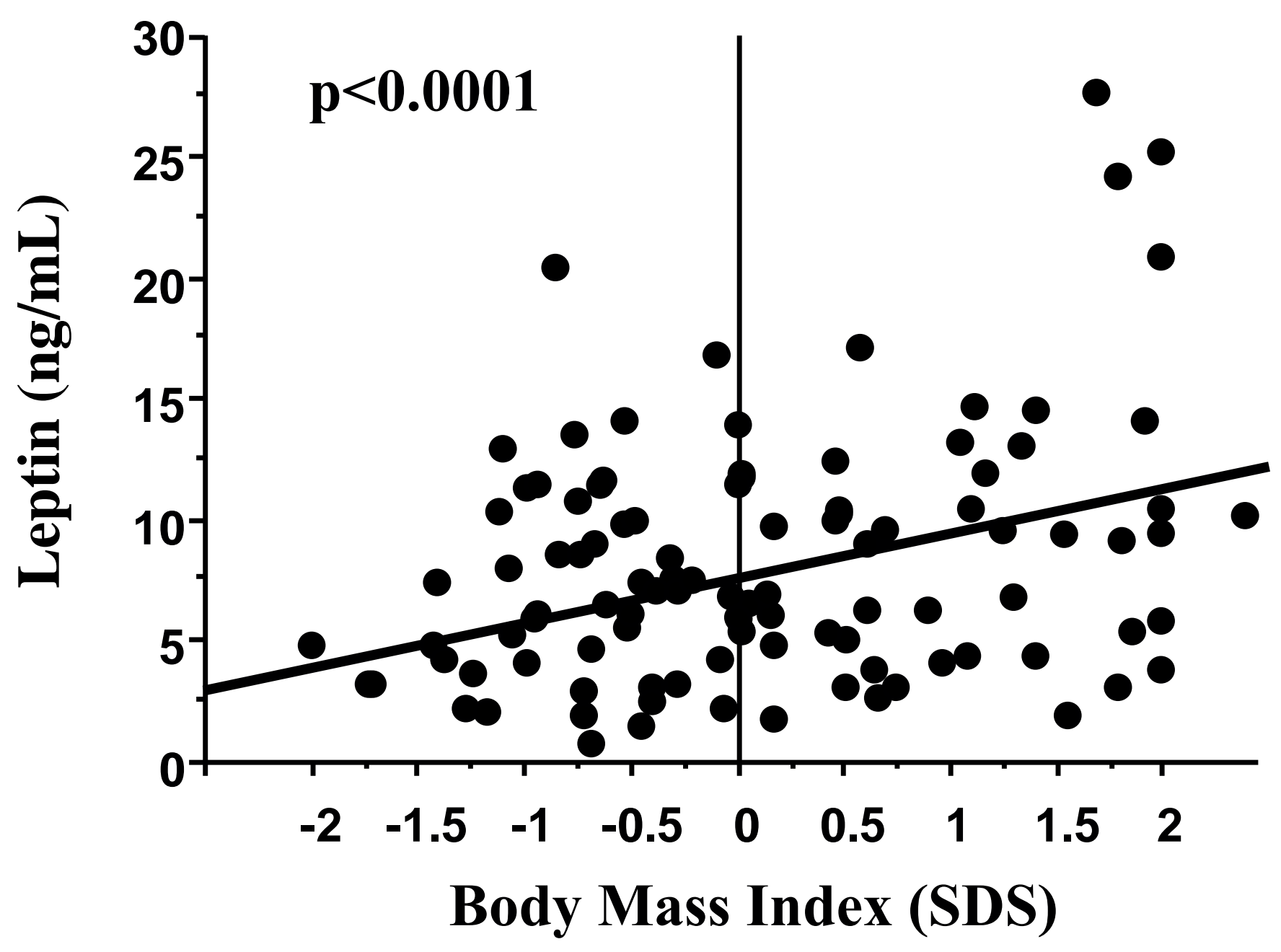

Figure 4B 


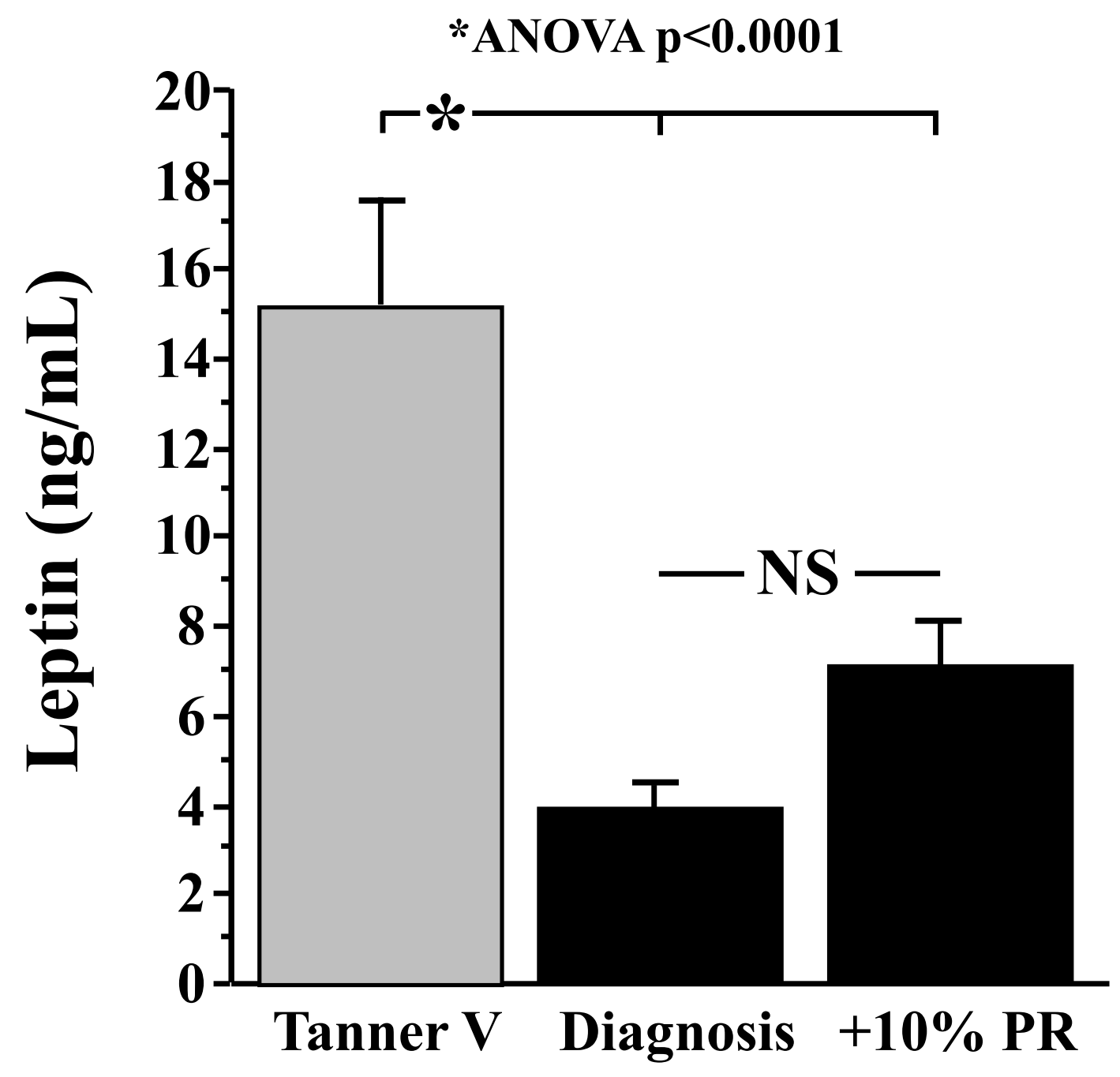

Figure 5 


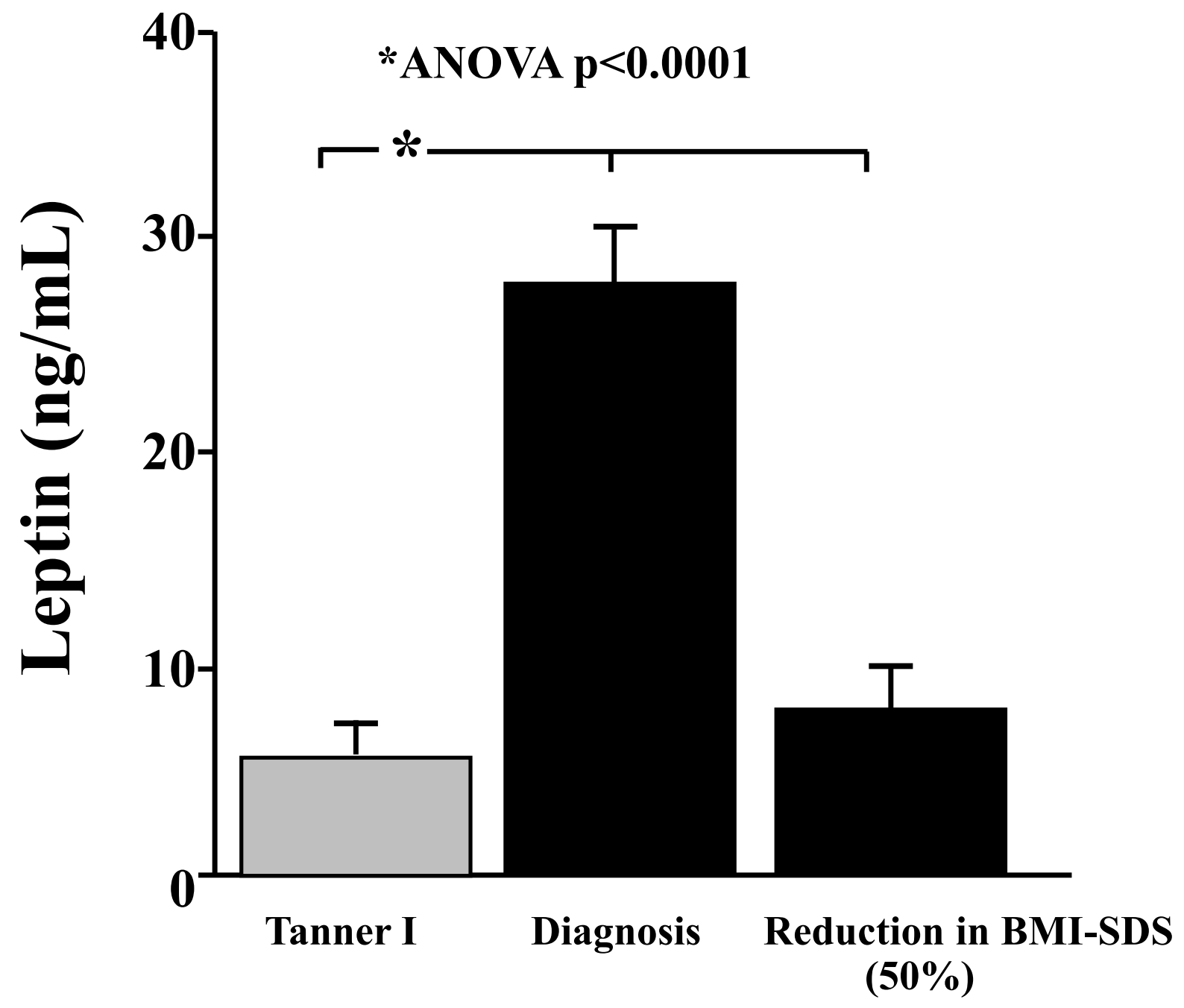

Figure 6 